\title{
Why is China's Blue Revolution so "Blue"? The determinants of conservation tillage in China
}

\author{
J. Wang, J. Huang, L. Zhang, S. Rozelle, and H.F. Farnsworth
}

\begin{abstract}
In response to problems associated with traditional tillage, over the past two decades, conservation agriculture (CA) has gradually emerged, and its adoption is becoming so widespread and benefits so great that it is being called the technology behind a new Blue Revolution. Somewhat surprisingly, given China's relatively strong track record in producing and spreading new cropping technologies, there is little information in the literature on the adoption of CA in China. The overall goal of this paper is to increase our understanding of the adoption of CA technology (or more precisely, the reduced tillage/residue retention part of the CA technology package, conservation tillage [CT]) and the constraints that exist to adoption in northern China. The objectives of this study include (1) obtaining valid data and providing a profile of CT adoption, (2) documenting both the extent and path of the adoption, and (3) measuring the determinants of CT adoption and trying to understand why it has emerged in some villages (and on some farms) but not in others. The data used in this paper come from our field survey of 292 households from four provinces in northern China. Based on the field survey, we have classified CT technology into Full CT technology (or Real CT technology - that is, those households that adopt both reduced tillage and residue retention together) and Partial CT technology (or Nominal CT technology - that is, those households that only adopt one of the components of Full CT technology, either reduced tillage or residue retention). Our results show that the adoption rates of CT technology (either for Full or Partial CT technology) are still low. Especially in the case of Full CT, adoption is almost zero. Despite relatively low rates of adoption, there are factors that are found to systematically encourage CT adoption. Our econometric results show that policies that ban burning crop residues, extension work that promotes CT technology, off-farm labor opportunities (which raise the opportunity cost of labor), and large farm size lead to higher adoption of CT technology.
\end{abstract}

Key words: adoption—China—conservation tillage—determinants

\begin{abstract}
Although China has been a leader in the developing world in the extension of many new agricultural technologiesfrom early Green Revolution semidwarf rice and wheat varieties, to hybrid rice, to genetically modified cotton (Huang and Rozelle 1996; Huang et al. 2002)-conservation agriculture (CA) technology has had a relatively low profile. Inside China, a large number of government-supported reports and scholarly articles have been published in the field of agronomy and agricultural mechanization (e.g., Huang 1988; Liu et al. 1989; Shi et al. 1990; Ding et al. 1994; Ji et al. 1998; Kang et al. 2001; Xie et al. 2007). However, in all of these articles
\end{abstract}

only used on about $1.5 \%$ of cultivated land. It is important to note that the government report is not clear as to the definition of CA that is being used. It could be that the area which is claimed to be using CA technology may, in fact, be counting practices that do not meet international standards for true CA technologies. Hence, although China's adoption of CA technology might be able to be called significant in recent years, it is hard to call it "revolutionary."

So, why is the level of CA technology adoption so low? Given China's proven ability to borrow, adapt, and extend new agricultural technologies from international sources, this is unclear. In addition, some of China's most important crops-wheat, maize, and soybeans-contain similar genetic material as those used in nations that are the largest adopters of CA technology. Many of China's climatic and soils conditions also are similar. A large share of China's grain production is concentrated in its northern regions, which receive relatively low rainfall. Soils there are often fragile. Hence, it would appear that CA technology would be a good candidate for adoption. However, despite the potential benefits, the relative difficulty of accessibility has contributed to the fact that the adoption of CA, especially conservation tillage (CT), by China's farmers is still low.

One explanation for the low adoption may simply be an absence of information about CA technology inside China. Surprisingly, despite the increasing importance of CA in the world and the interest that many lab- and field-based academics have had in CA technology, there is little, solid empirical research that documents the extent of CA technology across China. Also, while there have been many prescriptive reports written on how

and reports, there is little research about CA technology. The Ministry of Agriculture did not even mention CA technology in its diffusion material until the early 1990s (Yang and Song 2007). Today there are few statistics on the level of adoption of CA at the national level; most reports of CA technology are anecdotal. One government report $(\mathrm{Gu}$ 2008) claims that CA technology was being used by farmers on 2 million ha $(5$ million ac) of farmland in 2007. This source does not appear to be relying on the same source of adoption information as China's traditional system that records the area planted and major varieties on an annual basis. While this number is not zero, land-efficient CA is still
Jinxia Wang is a professor, Jikun Huang is a professor, and Lijuan Zhang is a senior research assistant in the Center for Chinese Agricultural Policy (CCAP), Institute of Geographical Sciences and Natural Resource Research, Chinese Academy of Sciences, Beijing, China. Scott Rozelle is a professor and senior fellow for the Program on Food Security and the Environment, Freeman Spogli Institute for International Studies at Stanford University, Palo Alto, California, and is also an adjunct professor at the University of Waikato, Hamilton City, New Zealand. Helen $\mathbf{F}$. Farnsworth is a senior fellow for the Program on Food Security and the Environment, Freeman Spogli Institute for International Studies, Stanford University, Stanford University, Palo Alto, California. 
CA technology should be applied, there is little in the literature that objectively decribes how it has actually evolved and spread. For example, since farmers do not have the necessary equipment, Shi et al. (2006) suggested that the government should support the research and production of no-tillage machinery to promote the development of CA in China.Yang and Song (2007) reported that since farmers do not have the necessary information on CA, most farmers in China do not understand the implications of CA technology. In particular, most farmers are unaware of the potential benefits of CA adoption. Therefore, in order to promote CA technology in China, more demonstration projects are needed. Other research (e.g., Dou 2007; Ma et al. 2006; Kang et al. 2001; Li 1999; Zhao et al. 1998; Zhang et al. 1995; Liu et al. 1994) also reports that, according to their experimental trials (although not in the fields of farmers), the adoption of CA technology can have a negative effect on yields. As a result, researchers suggest more research needs to be done on how to improve crop yields in the short term to provide a greater incentive for farmers to adopt CA technology. All of this literature is useful and helps improve our understanding of the challenges of promoting the adoption of CA in China. However, in no case has previous research been based on widespread, survey-based information collected from farmers in the field in China.

Because of this gap in the literature, there are many unanswered questions, including the following: What kinds of CA-related technology are farmers in China using? What is the extent of the adoption and time path of adoption of the technology? Why is CA practiced in some villages but not in others? Why do some farmers adopt CA but not others? More importantly, is CA an appropriate technology, given the nature of China's socioeconomic and natural endowments? Is its use appropriate today or will it be appropriate in the future?

The overall goal of our paper is to answer some of these questions in order to provide a better understanding of the adoption of CA technology and to identify constraints that might be limiting its diffusion. Our paper focuses on two specific objectives. First, we seek to provide a profile of CA adoption and identify the characteristics of CA technology that we find being used in the field. Second, we identify determinants of CA adoption and diffusion in order to measure those factors that can influence farmer's options when choosing the tillage practices.

Because this is such a broad topic, we necessarily must limit its scope. First, we only study northern China. Although there are many applications of CA technology that could be used in the climatic regions in south China, the technology's ability to improve the environment and conserve soil and water resources appear to be more appropriate for northern parts of the country. Furthermore, we focus on areas dominated by dryland agriculture. Although our sample covers a wide range of areas, we have focused on areas in which the government extension system and several key universities have targets for research on CA technology. Therefore, the estimates of the rates of adoption in China should be treated as an upper bound.

Why is northern China a place that is appropriate for the extension of CT? Northern China covers 16 provinces and contains $45 \%$ of China's population (National Statistic Bureau of China 2007). Although occupying 64\% of the nation's cultivated land, northern China only has $29 \%$ of its water resources (Ministry of Water Resources 2007). Due to the shortage of water resources, northern China is dominated by dryland farming, which makes its soil resources more vulnerable to natural forces, such as wind and heavy rainfall (Zhai and Deng 2000). The major crops in northern China are wheat, maize, cotton, soybean, and several crops (e.g., peanuts) that can be used to produce edible oil. The climatic conditions also are severe. For example, on average, rainfall is less than $750 \mathrm{~mm} \mathrm{y}^{-1}$ (30 in $\left.\mathrm{yr}^{-1}\right)$. In some regions, it is even lower than $200 \mathrm{~mm} \mathrm{y}^{-1}\left(8\right.$ in $\left.\mathrm{yr}^{-1}\right)$. In addition, farmers in northern China also have to deal with low winter temperatures, short frost-free periods $(<150$ days), and high rates of evaporation $\left(>1,500 \mathrm{~mm} \mathrm{y}^{-1}\left[>59\right.\right.$ in $\left.\left.\mathrm{yr}^{-1}\right]\right)$. Perhaps most importantly, when farmers use conventional tillage systems, some researchers believe that the structure of soils will be easily degraded and fertility will decline. These conditions may, in part, explain the low levels of water use efficiency and relatively low crop yields (Liu et al. 2004). According to the statistics of the Ministry of Water Resources (Ministry of Environmental Protection 2008), in China $37.1 \%$ of the land is suffering from some degree of "relatively serious" soil erosion. Of this amount, more than $70 \%$ of the eroded area is located in northern China. In addition, based on review of the literature, Jiao et al. (2008) found that estimates of actual soil loss rates and tolerable soil loss rates vary significantly across studies. Generally, however, in north China, the estimated actual soil loss rates are typically higher than tolerable soil loss rates. Therefore, considering the potential environmental benefits of CA or one subset of the technologies, CT in particular, as well as the nature of the technology (that is, it is an efficient use of land and it saves water), it is fair to say that CA or CT technology may be a more appropriate technology for extension in northern China than elsewhere in China.

We also need to limit the scope of our analysis in terms of the specific type of CA technology that we are studying. In the second part of our Background section, we describe the relationship between two types of technologies, CA (which is built on three principles - minimal soil disturbance, permanent soil cover, and crop rotations) and CT (which is built on two principles-minimal soil disturbance and permanent soil cover). Although international literature has mostly examined CA, because China's effort to promote this technology has not included an emphasis on crop rotations, our analysis focused on CT.

$A$ "Blue" Revolution in the World. Conventional agriculture is increasingly being criticized for its adverse environmental effects (Faulkner 1943; Ronald and Shirley 1984; CIMMYT 1993; Huszar et al. 1999; FAO 2001a; Ministry of Agriculture 2005; Geraghty 2007; Sthiannopkao et al. 2006; Pierret et al. 2008). Over the past 50 years, agriculture has become increasingly reliant on soil tillage and has become dependent on tractor-based capital and energy (FAO 2001a). The original theory was that plants were more productive in soils that had been plowed, disked, and harrowed since uniform, granular soil was thought to promote growth. While there may be positive returns to tillage in the short run, there are also costs-especially environmental costs that will be suffered in the long run. It also is clear that in at least some cases, costs may outweigh the benefits.

Recent research indicates that soil tillage using equipment such as ploughs, disks, harrows and rotary cultivators not only add to the cost of production of farmers, but repeated use over time can have detrimental 
effects on soil structure (e.g., the formation of a crust and/or compaction). This soil structural degradation can have several additional consequences. Some soils become more susceptible to erosion from wind and water (FAO 2001a; He et al. 2004; Ministry of Agriculture 2005; Gao 2006). More often it is the consequence of long-term soil erosion (loss of topsoil). While some soils may become more susceptible to soil erosion, in many cases, many soils already are susceptible to soil erosion because of the characteristics of the landscape and soil (Department for Environment, Food and Rural Affairs 2005) Clearly, both the government (e.g., Cai 2002; Li et al. 2008) and farmers (ACIAR 2005; Cao et al. 2008) understand erosion in China is a serious issue. As the awareness of the seriousness of soil erosion has emerged since the 1980s, the government has begun large-scale watershed management and ecological reconstruction programs in some of China's most soil erosion-prone regions (Yang et al. 2002). There have been a number of different efforts. For example, the government has organized farmers and workers to increase vegetation cover by tree planting and pasture cultivation. Officials have also tried to promote engineering measures, such as constructing terrace fields and building check-dam systems. Third, the government has also promoted agricultural-based measures, including CT. In fact, as reported by the Ministry of Water Resources, due to adoption of these control measures, the area affected by soil erosion has decreased, and the annual sediment load flowing into China's rivers (such as the Yellow River) has also decreased (Suo 2004). Although there has been considerable progress, soil erosion is still one of the most serious environmental issues in China. In other soils, water-in the form of rain or irrigation - has a more difficult time infiltrating into the soil. In some cases, increased runoff can carry topsoil and nutrients away with it. As noted by den Biggelaar et al. (2003), while most researchers agree that erosion is a serious problem, there is less agreement with regard to its on-site effects on agricultural production and soil productivity. Some research suggests that soil erosion has reduced crop yields significantly in the past and will continue to do so in the future. Other research suggests that yield losses have been small relative to historic yield growth resulting from increased input use and improvements in technology and that farmers have sufficient incentive in most cases to avoid erosion-induced yield losses. Because of the high cost of tillage, there is a new awareness about the overall benefit of technologies that can reduce these problems (FAO 2001b, 2001c; CIMMYT 1993).

Over the past two decades, CA has gradually emerged as a response to the realization that traditional tillage can lead to higher costs - for production and the environment. The benefits of CA are such that it is being called the technology behind a new Blue Revolution (FAO 2001a; Geraghty 2007) In its most basic form, instead of plowing and using other tillage operations, which require the use of capital (tractors), energy, and labor, farmers drill their seed directly into the soil. Since the soil, in general, is less disturbed, the plant cover on the top layer of the soil is kept intact. Herbicides are often used instead of plow-based weeding regimes. While there are cost savings from less labor and machinery, there are generally higher costs from greater chemical use. Many soils under CA have higher propensities to allow for improved water infiltration. When water infiltration improves, surface runoff decreases, which can reduce soil erosion and lessen the impact of short-term droughts. Without artificially disturbing the land on an annual (or seasonal) basis, biological processes in the soil are triggered, which may enhance the productivity of the agricultural production system. Managed properly, when farmers adhere to the strictest forms of CA, it is possible that their fields can create sinks for $\mathrm{CO}_{2}$, which can contribute to controlling air pollution and global warming - as well as lead to opportunities for selling carbon services-(Lal et al. 1999; ECCP 2003; Barker et al. 2007). In summary, CA can be a winwin technology, enhancing both profitability and sustainability. As Knowler and Bradshaw (2007) summarize, "Fortunately for the proponents of conservation tillage, its net financial impact at the individual farm scale appears positive as well. Since the seminal work of Crosson (1981), numerous financial analyses of conservation tillage adoption, whether in a developed world (e.g., Stonehouse 1997) or developing world (e.g., Sorrenson 1997 Sorrenson et al. 1998) context, have shown that it generally produces higher net returns relative to conventional tillage. This is largely true because of reduced costs for machinery, fuel, and labor, combined with unchanged or improved yields over time."
A new technology, however, can only be counted as a "Revolution" if it becomes widely adopted over a fairly short time period. According to this criterion, it would seem safe to say that the record of CA technology, globally, more than qualifies CA. The earliest record of CA technology was in the early 1970 s when about 10 countries reported the earliest phases of adoption (FAO 2001a). In 1974, the total area in the world that was using CA technology was less than 3 million ha (7.4 million ac), about $0.2 \%$ of global cultivated area. Ten years later, in 1984 , the total area under CA increased to more than 6 million ha (15 million ac). Since the 1980s, adoption rates accelerated in many countries. Between the early 1980 s and 2000 , CA area rose nearly 10 fold. By 2005, CA had been adopted by a large number of farmers covering nearly 100 million ha $(247$ million ac) in more than 20 countries, including the United States, Canada, Australia, Brazil, and Argentina (FAO 2006).

Definition of Conservation Tillage. As pointed out by Uri (1998), CT is defined as any tillage system that leaves enough crop residues on the field after harvest to protect the soil from erosion. Conservation tillage evolved from practices that range from reducing the number of trips over the field to raising crops without any primary or secondary tillage. A current emphasis internationally is on leaving crop residue on the surface of the field after planting (Lithourgidis et al. 2009). In general, tillage that leaves a residue cover of at least $30 \%$ on the soil surface is deemed CT (CTIC 2002). Residue cover is allowed to vary, however, according to soil type (soil texture), slope, crop cover, and other factors. Conservation tillage, as defined by the Conservation Technology Information Center (2002), includes four types of CT systems: no tillage, mulch tillage, ridge tillage, and reduced or minimum tillage. Strip-till is included among CT practices, as well. This is a form of noninversion tillage and subsoiling. From the above discussion, it is clear that there are two important fundamental components for the CT: minimal soil disturbance and permanent soil cover.

So what is the relationship between CT and CA? In the early 2000s, the Food and Agriculture Organization (FAO) created a new way of thinking about these technologies by making $\mathrm{CT}$ a part (albeit an important part) of CA (FAO 2001a). The difference, in fact, is fairly clear. According to the FAO, CA 
aims to achieve sustainable and profitable agriculture through the application of three principles: minimal soil disturbance, permanent soil cover, and careful crop rotation. The first two, minimal soil disturbance and permanent soil cover, are the basic building blocks of CT; CA is then equal to CT plus an emphasis on crop rotation.

So what is the nature of CA/CT technology in China? In 2007, the Ministry of Agriculture in China issued two important policy documents to promote the development of CA in China: "Suggestions on the Development of Conservation Agriculture" (Ministry of Agriculture 2008a) and "Technical Points of Conservation Agriculture Implementation" (Ministry of Agriculture 2008b). Based on these two documents, it can be seen that CA includes four components: no tillage or reduced tillage, the use of residue (or straw) to cover the soil (or residue retention), the adoption of no tillage or reduced tillage machinery, and the use of herbicides for the control of weeds in the field.

In addition, there is another consideration. For whatever reason (discussed in depth below), few of China's farmers have adopted what can be considered the full package of CT technology. At most, farmers adopt a set of components that ends up in only a partial adoption of CT technology. It is for this reason that we also have classified CT technology into two categories. The first type can be called Full CT technology; the second type can be called Partial CT technology. If farmers adopt both no tillage (or reduced tillage) and residue retention technologies at the same time, we call such practices Full CT technology. If farmers adopt only no tillage or reduced tillage technology or only residue retention technology, we call such practices Partial CT technology. It should be noted that Full CT technology is basically consistent with what is being called CT technology in the literature. Partial CT technology is not consistent with what most researchers consider CT technology. In fact, there is some evidence in the literature that suggest that when farmers adopt Partial CT technology, the impact on the environment could be even worse than if they had used more conventional agricultural approaches (Bolliger et al. 2006; Baudron et al. 2007; Kaumbuhto and Kienzle 2007). However, it also is possible that partial adoption is the first step towards full adoption. According to Giller et al. (2009), "In practice farmers have been found to not adopt all components of CT due to various reasons such as limited access to inputs (herbicides, cover crop seeds), labor constraints, or insufficient resources to grow cash crops continuously." As noted by Byerlee and Polanco (1986), such adoption behavior has been referred to as sequential adoption. Because of this possibility, we have decided to study both Full and Partial CT technologies. Of course, it could be that this assumption is not right. It could be that the adoption of Partial CT technology is not the first step towards adopting Full CT technology. If our assumption is wrong and the adoption of Partial CT will not lead to the adoption of Full CT, then the discussion in this paper about Partial CT should be ignored in the rest of the paper.

Understanding the Levels of Conservation Tillage Adoption. Why are China's rates of adoption of CT technology-especially the adoption of Full CT technology-so low? The first step in understanding the low levels of adoption-especially relative to some of the countries that are known for high levels of CT technology, for example the United States, Canada, and Brazil, etc.- -is to examine the nature of China's agricultural production practices, in general. The single, overwhelmingly defining characteristic of China's agriculture is that it is labor intensive. In 2005, according to China's National Development and Reform Commission cost of production database (NDRC 2006), the typical wheat (maize) farmer in China used 119 days (143 days) of labor in producing 1 ha $(2.5 \mathrm{ac})$ of their crops. According to the cost of production database notes, one day is equal to eight hours.

While this is much lower than in the 1980s and the early 1990s (indeed labor use per hectare in agriculture fell by nearly $50 \%$ between 1990 and 2005 [Brauw et al. 2008]), the use of labor on a per hectare basis is still far above that of producers in some of the largest CT-technology adopting countries. For example, in the United States, in order to produce 1 ha $(2.5 \mathrm{ac})$ of wheat or maize, farmers only used seven days of labor for wheat and eight days for maize (USDA ERS 2008). In Brazil, the typical farmer used 13 days of labor to produce 1 ha of maize.

While China's farmers use much more labor in crop production than their counterparts in the United States, Canada, and Brazil, the opposite is true in the case of machinery and fuel use. For example, in China, wheat farmers paid $\$ 114 \mathrm{ha}^{-1}\left(\$ 282 \mathrm{ac}^{-1}\right)$ for their machinery, while maize farmers paid $\$ 60$ $\mathrm{ha}^{-1}\left(\$ 148 \mathrm{ac}^{-1}\right)$ (NDRC 2006). While in the United States, the wheat farmer expended $\$ 157 \mathrm{ha}^{-1}\left(\$ 388 \mathrm{ac}^{-1}\right)$ on machinery, while a maize farmer expended $\$ 200 \mathrm{ha}^{-1} \quad$ \$494 $\mathrm{ac}^{-1}$ ) (USDA ERS 2008). In addition, in order to produce 1 ha $(2.5 \mathrm{ac})$ of crop, the farmer in China only needed to spend $\$ 0.86$ (for wheat) or $\$ 0.69$ (for maize) on fuel directly. While in the United States, farmers expended $\$ 44$ for wheat ( $\$ 71$ for maize) for fuel for producing 1 ha $(2.5 \mathrm{ac})$ (USDA ERS 2008). In Canada and Brazil, machinery and fuels costs were also much higher (Zentner et al. 2002). For example, the typical soybean farmer in Brazil expended $\$ 168$ ha $^{-1}$ (\$415 $\mathrm{ac}^{-1}$ ) for machinery and fuel.

The reason for these large discrepancies in production practices between China and other CT-technology adopting countries, of course, is related to the sharp differences in the relative level of factor prices. The unskilled wage in China is only $\$ 2$ day $^{-1}$ (NDRC 2006). In contrast, it is about $\$ 80$ in the United States, $\$ 76$ in Canada, and nearly $\$ 40$ in Brazil (USDA ERS 2008). In addition, the farm size in China is much smaller than that in other countries. For example, the average farm size in China is about 0.5 ha $(1.2 \mathrm{ac})$, while it is $186 \mathrm{ha}(459 \mathrm{ac})$ in the United States, 73 ha $(180 \mathrm{ac})$ in Brazil, and 270 ha $(667 \mathrm{ac})$ in Canada. The various land sizes between countries results in the differences on the opportunity cost of land. In China, the pure rental rate is more than $\$ 500$ $\mathrm{ha}^{-1}\left(\$ 1,235 \mathrm{ac}^{-1}\right)$ (NDRC 2006), substantially higher than that in the United States, Canada, and Brazil. For example, in the United States, the rental rate is about $\$ 100$ for 1 ha $(2.5$ ac) of wheat land; it is about $\$ 225$ for maize land (USDA ERS 2008). In Brazil, 1 ha of prime soybean land can be rented for about \$25 (Assunção 2005). In Canada, the rental rate for spring wheat is $\$ 17$ (Wharton and Howes 2008).

Because of the high wage rate and land rental cost, it can be seen why farmers in the United States, Canada, and Brazil want to do everything they can to save on labor expenses and thus why they are willing to use more fuel and machinery. Research in the United States indicates that CT technology can save a farmer $50 \%$ to $60 \%$ of his labor (FAO 2001b). In addition, farmers can lower their machinery and fuel costs (Crosson 1981; 


\section{Table 1}

Share of sown area adopting conservation tillage (CT) technology and nature of labor and machinery input using CT and conventional agriculture in China in 2005.

\begin{tabular}{|c|c|c|c|c|}
\hline & \multicolumn{2}{|c|}{ Partial CT technology } & \multicolumn{2}{|l|}{ Full CT technology } \\
\hline \multicolumn{5}{|l|}{ Labor input (days ha-1) } \\
\hline Wheat & - & - & 45 & 120 \\
\hline \multicolumn{5}{|l|}{ Machinery input (US dollars ha-1) } \\
\hline Wheat & - & - & 26 & 101 \\
\hline Maize & - & - & 22 & 46 \\
\hline
\end{tabular}

Mueller et al. 1985; Uri 2000; FAO 2001b; Mitchell et al. 2006). Clearly, when wages are so high, and machinery/fuel costs are such a large share of the cost of production (as they are in the United States, Canada, and Brazil), it is easy to see why farmers in these countries have made the Blue Revolution a true revolution.

It is important to note that we are not saying that there are not labor and machinery/fuel savings in China. In fact, there are. For example, based on a set of CT experiments in the Yellow River Basin, after adopting CT, farmers were able to save more than 30\% of their labor input (Yuan 2008; Zheng and Yao 2008; Wang 2008; Liu 2008; Yan 2008). Other studies have found that CT technology can also reduce machinery costs in China by $10 \%$ to $20 \%$ or more (Zhao and Shi 2006; Ma et al. 2006).

Our own data support the findings of research elsewhere in China. Specifically, we see that there are savings in both labor and machinery costs when farmers adopt CT technology (table 1). In the case of wheat, for example, when farmers adopt the Full CT technology package, labor input per hectare falls by nearly $60 \%$ (from 120 to 45 days). In the case of maize farmers, the reduction in labor is more than $40 \%$. Our survey also demonstrates that adopting the Full CT technology package can save machinery costs. For example, when comparing the use of machinery on the Full CT technology package with that used for conventional agriculture, there is a measured reduction of $75 \%$ in the case of wheat and $52 \%$ for maize production.

So why have farmers in China not swarmed to CT technology as they have in certain other parts of the world? One of the reasons most certainly is the nature of their agricultural production practices. Agriculture in China is conducted by individual households, a practice that has been in place since the early 1980s. Specifically, farmers have long-term use rights to the land; they make all decisions on their own (that is, they have full control rights), and they keep all profits and suffer all losses (that is, they have full income rights). Therefore, it is fair to assume that farmers seek to maximize profit and make all decisions, including the decision to adopt new technologies on their own. While farmers in China certainly would be happy to save labor and machinery costs, their labor costs per unit of input are so low (especially in the past) and their machinery costs account for a relatively low share of production costs so there is less of an incentive to do so. Given a choice, however, it is conceivable that China's farmers would be much more interested in technologies that saved on their scarcest factor-land.

So what is the relative benefit of CT technology in producing an efficient use of land (or higher yields) compared to conventional technologies? This may provide us the answer. A large body of international literature demonstrates that the adoption of CT technology mainly obtains yield benefits in the long run (Li et al. 2007; Wang et al. 2006; Choudhary and Baker 1994). It may take up to 10 years to realize any yield benefits. In the short term, the effects of CT technology on crop yield are variable, and most effects are neutral or negative (Giller et al. 2008; FAO 2006; Olson et al. 2004; FAO 2001a; Mbagwu 1990; Gill and Aulakh 1990). However, in the case of developing countries (including China), the short-term benefits are extremely important since they will determine the extent to which the CT will attract the farmers-who often are more interested in present earnings than in future earnings (as is the case of most farmers from poor developing countries) (Giller et al. 2008).

In the agronomy literature in China, the results of the research on effects of CT technology are mostly negative (at least in the short run). For example, according to one set of experiments in the Yellow River Basin from 2005 to 2008, in nearly a quarter of the trials, CT technology produced lower yields than conventional agriculture (Yuan 2008; Zheng and Yao 2008; Wang 2008; Liu 2008; Yan 2008). There are also many other cases in which agronomic research teams report that the adoption of CT technology would have a negative yield effect (at least in the short term) in at least some of their trials (Dou 2007; Ma et al. 2006; Kang et al. 2001; Li 1999; Zhao et al. 1998; Zhang et al. 1995; Liu et al. 1994). Hence, one reason that China's farmers are reluctant to adopt CT technology is that they-like their counterparts in other poor developing countries-are unwilling to adopt a technology that provides lower yields (that is, a technology that does not save on the scarcest resource-land) even if this is true only in the short run (Reardon and Vosti 1997; Shiferaw and Holden 2000; Field 2001). The yield benefits from CT are also possibly related with the management of the production system.

So in summary, from this analysis, we see that when farmers adopt CT technology, like their counterparts in Brazil and the United States, they do save on labor and machinery costs. However, since the unskilled wage is so low and since the share of costs contributed by fuel (machinery) is so small, the overall cost savings from the adoption of CT technology is relatively low in China. With land being so scarce, farmers want to maximize 


\section{Figure 1}

Location of four sample provinces in China.

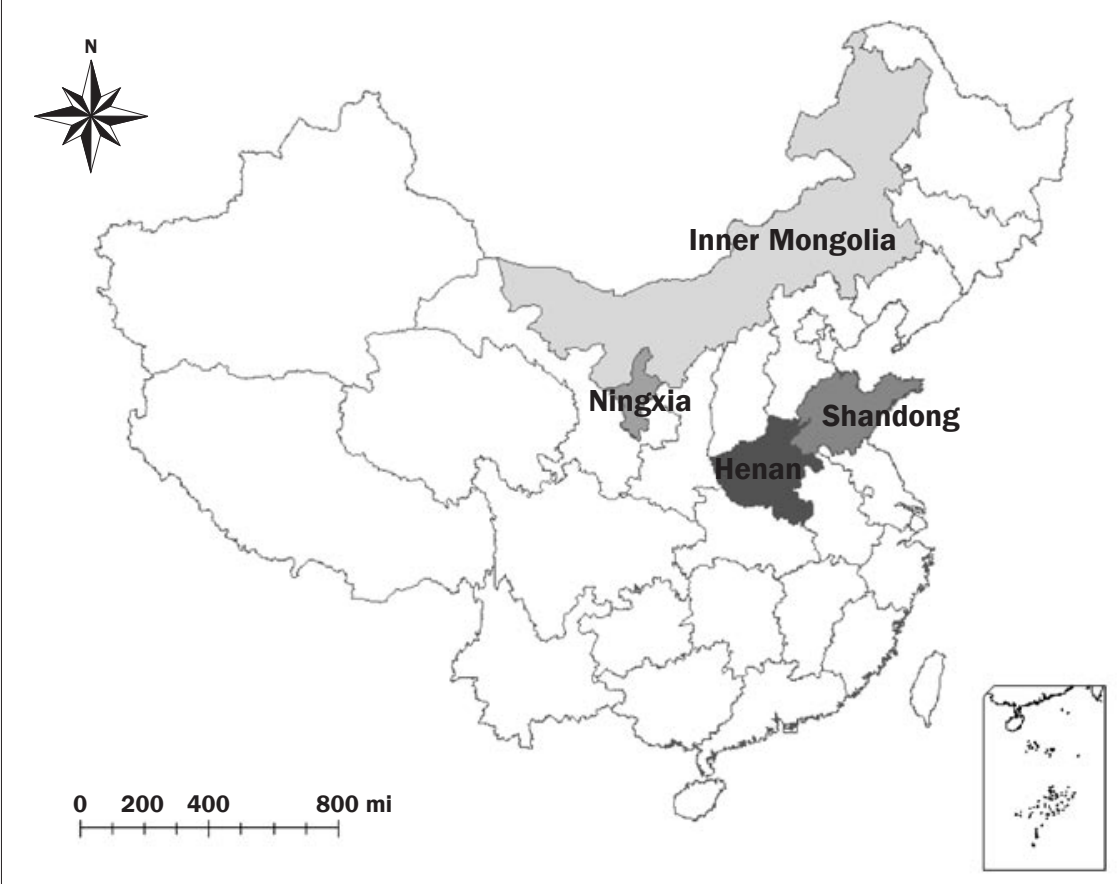

the output and so they are more reluctant to adopt CT technology since there is no guarantee that there is not a yield penalty. There are two major reasons for China's land scarcity. First, the nation's population is large, and its arable land is limited. This makes China's land per capita levels low. Second, as China has industrialized and urbanized, cultivated land is decreasing. It is for these many reasons that there may be less interest in CT technology in China.

Past Behavior; Future Demands. While it may have been true that in the past China's farmers have not been very interested in technologies that save labor and minimize fuel/machinery consumption, this does not mean that in the future it will be so. There is a lot of evidence that factor prices will be changing in the coming years - in some cases radically so. For example, it is becoming increasingly clear that the unskilled wage rate is rising in China (Park et al. 2008). Between 2005 and 2006, for example, it is documented that unskilled wages rose by almost 10\%. Given the demands for labor in a rapidly developing country and the relatively slow rate of growth of China's labor force (because of the one child policy and other factors associated with the demographic transition), wages are expected to continue to rise in the coming years. Therefore, it is almost certain that China's farmers will begin to become more eager to search out technologies that save on increasingly expensive labor. This will be equally true if the technology also saves on machinery and fuel, since as wages rise and labor moves out of agriculture, machinery and fuel will become an increasingly important part of China's production practices.

Therefore, despite the relatively low levels of adoption of CT technology now, it is still of interest to know why it is that some farmers (villages) adopt CT technology and others do not. Certainly, the low rates of adoption must have something to do with not only the characteristics of the CT technology but also with the nature of farming (and the characteristics of farmers) in China. Since there are differences in rates of adoption across our sample areas, it is possible that even now (with adoption rates relatively low) we may determine factors that promote (constrain) CT technology adoption. In the following section, based on our survey data, we will use both descriptive and multivariate analyses to examine the factors that affect the adoption of CT technology (both Full and Partial technologies).

\section{Materials and Methods}

Data. The analysis in this paper is based on a dataset that was collected from farmers and village leaders in northern China. Village leaders are the persons in each community that have been elected to run the governmental body (called the village management committee). This committee-in most villages - is in charge of all relevant management issues in the villages. The field survey and associated data work were organized by the Center for Chinese Agricultural Policy (CCAP) Chinese Academy of Sciences (CAS) in 2005 and 2006. The response rate for the survey was $100 \%$. We conducted the survey ourselves. All of the enumerators were $\mathrm{PhD}$ students from our institute (and other agricultural universities in China). We provided rigorous in the classroom and in the field training before they went to the field for the survey. In order to ensure the survey data quality, we required the survey team leader to check the survey tables every night. Because of the care taken during the preparation for and execution of the enumeration, we were able to obtain a response rate of $100 \%$, and we believe the data quality is high. The survey covered 49 villages and 292 households from eight counties in four provinces in northern China (figure 1). The four study provinces are all located in the Yellow River Basin. Two provinces-Ningxia and Inner Mongolia-are from the upper reaches of the Yellow River Basin. The other two provinces-Henan and Shandong - are from the lower reaches of the basin.

Within each province, we selected two counties that had CT projects that were funded by the Challenge Program of the Consultant Group of International Agricultural Research and jointly run by project participants and members of the local extension station. Within each county, we then randomly selected (according to a stratified approach) a set of villages and households (Des Raj 1998). Stratified random sampling is just partitioning the population into smaller groups, treating each section as a new population, then selecting a sample from each group independently of the other groups. One set of villages was drawn from villages that were being targeted for the extension of CT projects. The list of these villages was provided to the authors by the agricultural department of each county. The other set of villages was drawn from the other villages in the county (i.e., those with no known participation in a formal CT extension project-though in some cases there were local extension agents promoting different variants of CT technology). 
Table 2

Descriptive statistics of variables in both village and household models.

\begin{tabular}{|c|c|c|c|c|}
\hline & Mean & Standard deviation & Minimum & Maximum \\
\hline \multicolumn{5}{|l|}{ Variables used in the village-level analysis } \\
\hline If adopt Full CT technology ( $1=$ yes; $0=$ no) & 0.08 & 0.28 & 0 & 1 \\
\hline If does not adopt CT technology $(1=$ yes; $0=$ no $)$ & 0.54 & 0.5 & 0 & 1 \\
\hline Subsidy for machinery ( 1 = yes; $0=$ no) & 0.06 & 0.24 & 0 & 1 \\
\hline Forbid burning residue ( $1=$ yes; $0=$ no) & 0.48 & 0.5 & 0 & 1 \\
\hline Share of irrigated land area & 0.13 & 0.22 & 0 & 1 \\
\hline Per capita cultivated land area (ha) & 0.29 & 0.25 & 0.02 & 0.98 \\
\hline Distance to township (km) & 2.71 & 4.4 & 0 & 24 \\
\hline \multicolumn{5}{|l|}{ Variables used in the household-level analysis } \\
\hline If adopt Full CT technology (1 = yes; $0=$ no) & 0.06 & 0.5 & 0 & 1 \\
\hline Share of nonagricultural labor force & 0.24 & 0.28 & 0 & 1 \\
\hline Per capita cultivated land areas (ha) & 0.41 & 0.57 & 0.02 & 4.44 \\
\hline Share of irrigated plots & 0.27 & 0.31 & 0 & 1 \\
\hline Has draft animals ( $1=$ yes; $0=$ no $)$ & 0.36 & 0.48 & 0 & 1 \\
\hline Value of house (log) & 9.37 & 1.41 & 4.61 & 12.74 \\
\hline Age of household head (years) & 48 & 10 & 25 & 75 \\
\hline Education of household head (years) & 7 & 3 & 0 & 18 \\
\hline Share of loam plots & 0.25 & 0.42 & 0 & 1 \\
\hline Share of clay plots & 0.46 & 0.46 & 0 & 1 \\
\hline
\end{tabular}

Note: $\mathrm{CT}$ = conservation tillage.

The CT demonstration projects/extension efforts were almost all funded either by the central or regional (provincial/prefectural/ county) government or international organizations (such as the Consultant Group of International Agricultural Research) and were carried out by agronomists from the local agricultural extension system (as well as by professors from the local agricultural college/university system). Although our sample villages cannot be counted as a national representative set of villages, they are randomly selected in parts of China where many key informants (including agronomists and other agricultural scientists) believe that CT technology has the best chances of being adopted in the future. Finally, within the sample villages, a minimum of five households were randomly selected and surveyed. In the villages that had CT projects, we sampled from one strata of those farmers that were part of the project and from the other strata of farmers that were not part of the project.

Within each sample village, two surveys were carried out. The first was a village-level survey with key village leader informants. The village survey obtained general infor- mation about the village (e.g., demographics, per capita income, infrastructure, land use, the main cropping rotations, crop productivity, and major village income sources). The enumerators also asked about specific information related to the adoption (or lack thereof) of CT technology. Questions were asked about machinery utilization and availability, the importance of livestock, residue use, soil information, and government subsidies. Detailed information was recorded about the nature of the CT technology extension program (if one was present). The second part of the survey was targeted at sample households in the sample villages. The household survey enumerators obtained detailed information on each household's demographic structure, employment history, and asset base, as well as other information on the income stream from family members. Descriptive statistics of the main village-level and household-level variables are shown in table 2.

Indicators Measuring the Level of Conservation Tillage Adoption. To understand the adoption of CT technology in China, we use two sets of measures derived from our survey data. First, we use a villagelevel measure. According to this measure, a village is considered to have adopted a $\mathrm{CT}$ technology (either Full or Partial CT technology) if at least one plot of one farm household in the village uses the CT technology. While this does not mean that all, or even most, farmers in a village are using a given technology, information on how many villages have at least one farmer using a technology provides an understanding of how spatially pervasive a practice has become. The second measure, the percentage of sown area on which a new technology is being used, is a measure of the actual extent of adoption at the farm level.

In order to have a better understanding of the determinants of the adoption of CT technology, we conducted multivatiate analyses to separate the influence of each factor. Not only village level was examined; we also conducted household level analyses. There are a number of reasons to conduct the analysis at both the village and household levels. First, if we run the analysis at both levels and the results are similar, it will build confidence in the results (due to the fact that the results 


\section{Figure 2}

Share of villages adopting conservation tillage (CT) technology from 1980 to 2005 .

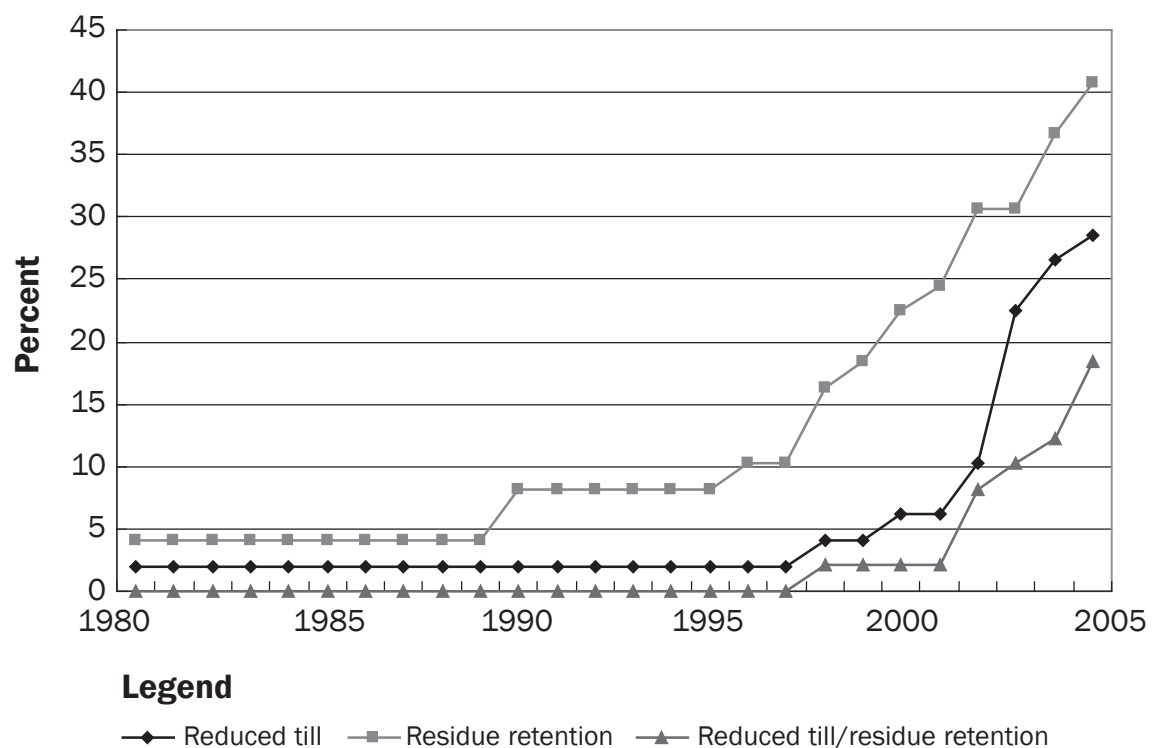

Note: Reduced tillage and residue retention technologies are both Partial CT technologies; reduced tillages/residue retention is Full CT technology.

are robust). Second, since the adoption of CT technology is still a relative rare event, this is a way to gauge its spread across space without resorting to a much larger sample of households. Such a strategy is often used in data collection efforts (e.g., polling hospitals for incidences of rare disease and polling schools for incidences of rare student types). It is for this reason that we do the analysis at both the village and household levels.

At the village level, we constructed the following multinomial logit model to explain the determinants of the adoption of CT technology measured (Greene 1997; CIMMYT 1993; Clay 2002; Bekele 2003):

$Y_{i k}=f\left(S_{i k}, P_{i k}, I_{i k}, D_{i k}\right)$.

In the model, $y_{i k}$ represents the adoption of CT technology in village $k$ in year $i$. If the village adopts Full CT technology, $y_{i k}=$ 1 ; if it adopts Partial CT technology, $y_{i k}=2$. Otherwise, for nonadopting villages, $y_{i k}=3$. The rest of the variables are those variables that explain the adoption of CT technology. The vector of $\mathrm{S}_{i k}$ represents a set of socioeconomic variables, measured by the share of the family's labor that is working off the farm, per capita cultivated land area, the share of cultivated land that is irrigated, and the distance of the household to township.

We also included two policy variables $\left(P_{i k}\right)$. The first variable measures whether or not there is subsidy policy in the village that encourages the purchase of machinery (which is equal to one when farmers in the village can get a subsidy and is zero otherwise). The other policy variable measures if there is a regulation in the locality that bans the burning of crop residue (which is measured as one if village leaders know there is such a policy and is zero otherwise).

In addition, we included a variable to measure the extent of the government's effort to promote CT technology. Specifically, the variable $\left(I_{i k}\right)$ measures the influence of whether or not there was a CT technology extension project in the village. This variable is measured as a dummy variable. If there was an extension project in the village at some time in the past (or currently), the variable is set equal to one; otherwise, it is zero. Finally, we also included county dummies $\left(D_{i k}\right)$ to control the unobserved county effects.

In order to understand why some households adopt CT technology and others do not, we also constructed the following multinomial logit model at the household level:
$T_{j}=f\left(H_{j}, P_{i k}, I_{i k}, D_{i k}\right)$

In this model, $T_{j}$ represents the adoption of CT technology by household $j$. In our analysis, this is set equal to one if the household adopts Full CT technology; if the household adopts Partial CT technology, $T_{j}=2$. Otherwise, for nonadopting households, $T_{j}=3$. The rest of the variables are those variables that explain the adoption of CT technology at the household level (and in many cases are similar to those used in equation 1). The vector, $H_{j}$, represents the socioeconomic characteristics of the household that affect adoption. Most importantly, we included two household variables that measure the family's labor (share of family members in the off-farm sector) and land endowments (per capita cultivated land holdings). We also included other variables as controls (e.g., the age and education of the household head). A wealth variable (which is measured as the value of the family's housing assets) is included as a control for whether or not the household was facing a liquidity constraint. In addition, we also control the possible influence of soil type on the adoption of CT, measured by the share of plots that are made up of loam soil and share of plots that are made up of clay soil.

In addition to household-specific variables, we included a number of policy and extension variables. These variables are measured at the household level, and the implications are similar to that in the village-level models. For the policy variable $\left(P_{i k}\right)$, we only included one variable that measures whether not the household knows that there is a residue burning ban.

\section{Results and Discussion}

Adoption of Conservation Tillage Technology. According to our survey, when using the village-level measure of adoption, CT technology has expanded in recent years, especially since the late 1990s and early 2000s. In the 1980s, the adoption rates of reduced tillage and residue retention (by themselves) were both low (figure 2). On average, only $2 \%$ of villages had any farmers that practiced reduced tillage, and only $4 \%$ of villages adopted some form of residue retention technology. The adoption of residue retention, while initially growing slowly in the early 1990s, accelerated after the mid-1990s. Although the adoption rates 
of reduced tillage started more slowly, farmers began to adopt it in the late 1990s, and its adoption rate has been growing rapidly thereafter. By the last year of our data collection, there was at least one farmer using residue retention in $41 \%$ of our sample villages, and there were more than $28 \%$ of the sample villages in which at least one farmer was practicing reduced tillage.

The adoption path of Full CT technology follows a similar trend as that of residue retention but with somewhat lower adoption rates (figure 2). In fact, from the early 1980 s to the late 1990s, there was not even one farmer in any of the villages that had adopted the Full CT technology package. In the late 1990s, the percent of villages rose slightly (to $2 \%$ of the villages). After 2001 , however, the adoption of the Full CT technology rose gradually. From 2000 to 2005, the share of villages adopting Full CT technology increased to $18 \%$.

When using household-level measures of the adoption of CT technology and the share of sown areas adopting CT, the most striking findings of our adoption analysis are revealed. Results show that while Full CT technology adoption level was low (3\%), the Partial CT technology adoption reached $33 \%$ in 2005 (table 1). It should be noted that this level of adoption needs to be kept in context. That is, this level of technology adoption occurred in areas where the government is actively promoting the technology. We believe if one were to do a wider, fully random sample of villages, the levels of adoption of Full CT technology would almost certainly be lower.

Differences Across Provinces. Although adoption levels using village-level measures are fairly low across our whole sample (at least until the most recent years of our study period), we do observe differences among provinces in the adoption pathways of CT technology (table 3). For example, in 92\% of the sample villages in Henan Province, at least one farmer used residue retention technology in 2005 (that is, one type of partial CT technology) (table 4). In contrast, farmers in only $17 \%$ of villages in our Ningxia Province sample villages used this technology. Adoption of residue retention in Shandong and Inner Mongolia provinces were in between.

There are also variations among provinces in the adoption levels of reduced tillage in 2005 (table 4). In $62 \%$ of the sample villages in Inner Mongolia, at least one household
Table 3

Adoption rates of the Full and Partial conservation tillage (CT) technology by sown area in China in 2005.

\begin{tabular}{|c|c|c|c|c|c|}
\hline & \multicolumn{5}{|c|}{ Share of sown areas adopting CT technology (\%) } \\
\hline & Ningxia & $\begin{array}{l}\text { Inner } \\
\text { Mongolia }\end{array}$ & Henan & Shandong & Average \\
\hline \multicolumn{6}{|l|}{ Partial CT technology } \\
\hline Reduced till & 1 & 6 & 7 & 0 & 6 \\
\hline Residue retention & $<1$ & 10 & 44 & 35 & 27 \\
\hline \multicolumn{6}{|l|}{ Full CT technology } \\
\hline Reduced till and residue retention & $<1$ & 4 & 0 & 1 & 3 \\
\hline
\end{tabular}

\section{Table 4}

Adoption rates of the full and partial conservation tillage (CT) technology by village in China in 2005.

\begin{tabular}{|c|c|c|c|c|c|}
\hline & \multicolumn{5}{|c|}{ Share of villages adopting CT technology (\%) } \\
\hline & Ningxia & $\begin{array}{l}\text { Inner } \\
\text { Mongolia }\end{array}$ & Henan & Shandong & Average \\
\hline \multicolumn{6}{|l|}{ Partial CT technology } \\
\hline Reduced till & 8 & 62 & 42 & 0 & 28 \\
\hline$\underline{\text { Residue retention }}$ & 17 & 23 & 92 & 33 & 41 \\
\hline \multicolumn{6}{|l|}{ Full CT technology } \\
\hline Reduced till and residue retention & 0 & 39 & 16 & 17 & 18 \\
\hline
\end{tabular}

adopted reduced tillage technology. During the same period, reduced tillage could only be found in $8 \%$ of villages in Ningxia Province. This technology could not be found in any of the Shandong villages.

In the case of the adoption of Full CT technology using the village-level measures, there also are differences across our sample provinces (table 4). In 39\% of the sample villages in Inner Mongolia, at least one farmer adopted the Full CT technology. The levels were lower in Henan (16\%) and Shandong (17\%). Strikingly, there were no villages in our sample villages in Ningxia Province that adopted Full CT technology-despite the efforts of the government to promote the technology.

Factors Influencing the Adoption of Conservation Tillage Technology. In the following section, we will first look at cross tabulations between measures of CT technology adoption and a set of socioeconomic factors that define the nature of China's villages and the farmers in the villages. We also will examine if policy and extension/research projects that have attempted to provide information to producers about the benefits of CT technology are correlated with rates of adoption.

Descriptive Statistics Results. Some of the most distinguishing characteristics of and those that do not are seen by comparing access to household labor and land resources. Results show that for those villages adopting the Full or Partial CT technology, the share of the labor force that is working off the farm (30\% to $50 \%)$ is higher than in those villages without Full or Partial CT technology (24\%) (table 5). Therefore, according to our data, if farmers have better off-farm opportunities, they appear to be more interested in adopting CT technology. This, of course, accords with the discussion in the preceding section explaining the differences in adoption among countries (e.g., between China and the United States, Canada, and Brazil). Even within China, if the villages that have more of their labor force in the off-farm sector have a higher opportunity cost for labor, our descriptive data suggest that these villages may be more interested in the labor-saving benefits of CT technology (either Full or Partial CT technology).

Likewise, our survey data also indicate that farmers in those villages that have more land area are more likley to adopt Full CT technology (table 5). This, too, is consistent with the discussion of cross country comparisons of adoption. When land is more scarce, such as about 0.25 ha per capita $(0.62$ ac per capita), our data suggest that farmers are rela- those producers that adopt CT technology 
Table 5

Village-level and household-level factors influencing the adoption of conservation tillage (CT) technology in China in 2005.

\begin{tabular}{|c|c|c|c|c|c|}
\hline & Full CT & Partial CT & No adoption & $t$-test† & $t$-test‡ \\
\hline \multicolumn{6}{|l|}{ Socioeconomic factors } \\
\hline Per capita cultivated land area (ha) & 0.38 & 0.22 & 0.25 & $6.45 * * *$ & $5.17 * * *$ \\
\hline Share of irrigated land area (\%) & 22 & 16 & 9 & 1.86 & $3.33 * * *$ \\
\hline \multicolumn{6}{|l|}{ Government policies } \\
\hline Villages aware of policy that bans burning residue (\%) & 88 & 54 & 38 & $2.05 *$ & 1.3 \\
\hline \multicolumn{6}{|l|}{ CT-relevant extension projects } \\
\hline Villages that have CT project (\%) & 63 & 27 & 6 & 1.43 & $2.74 * * *$ \\
\hline \multicolumn{6}{|l|}{ Household-level analysis } \\
\hline \multicolumn{6}{|l|}{ Socioeconomic factors } \\
\hline House value of household (US dollars) & 1,933 & 5,373 & 2,532 & 0.1 & $4.53 * * *$ \\
\hline \multicolumn{6}{|l|}{ Government policies } \\
\hline Households that know about policy that bans burning residue (\%) & 53 & 28 & 19 & 1.73 & 1.41 \\
\hline \multicolumn{6}{|l|}{ CT-relevant extension projects } \\
\hline Households participating in CT project (\%) & 76 & 34 & 6 & $2.75 * *$ & $5.78 * * *$ \\
\hline \multicolumn{6}{|c|}{$\begin{array}{l}\text { Notes: Full CT implies that villages/farmers adopted both reduced till and residue retention together. Partial CT implies that villages/farmers only } \\
\text { adopted one of the components of Full CT technology-either reduced tillage or residue retention. }\end{array}$} \\
\hline \multicolumn{6}{|l|}{$\dagger t$-test was to test the mean difference between Full CT and no adoption. } \\
\hline \multicolumn{6}{|l|}{$\ddagger t$-test was to test the mean difference between Partial CT and no adoption. } \\
\hline * significant at $10 \% * *$ significant at $5 \% * * *$ significant at $1 \%$ & & & & & \\
\hline
\end{tabular}

tively more interested in adopting Full CT technology, even though there may be a yield penalty (or at least there is no yield gain) in the short run. While yields may go down, reducing crop revenue, cost savings may be greater, improving profits overall. It will be situation dependent. Compared to the case of Full CT technology, the adoption of partial CT appears to be less affected by the relative quantity of the land resource (table 5).

Beyond factor endowments, access to policy support may also influence the adoption of CT technology (CIMMYT 1993; FAO $2001 \mathrm{~b}$ ). Before investing in any soil or water conservation practice (or any new technologies), farmers will have to be convinced that the benefits will be greater than the costs (assuming risk neutrality); farmers often have to overcome some type of constraint (Ervin and Ervin 1982; Reardon and Vosti 1995; Clay et al. 2002). Because these uncertainties and constraints may mean that farmers do not see immediate gain from the technology, government support policies (for financial aid and infrastructure construction) are often associated with successful adoption of CT technology (Reardon and Vosti 1997; Malla 1999; Sanders and Cahill 1999; Bekele 2003). Specifically, when the government provides subsidies or loans to encourage adoption, we would expect to see more adoption.

The data from our study sites, in fact, do show that policy support possibly influences the adoption of CT. When examining the data about the village-level measures of adoption, we see that if the government provides subsidies for machinery that can be used for developing CT technology, the probability of a farmer in a village adopting CT technology $(13 \%$ or $11 \%$ for those villages adopting either full or partial CT technology) is higher than in nonadopting villages (2\%) (table 5). The result also implies that if the cost of replacing an existing machine is relatively low, it may be easier to extend CT technology in the field.

Policies can also create barriers. For example, because of concerns about air pollution, many localities in China (and elsewhere in the world) are taking steps to prohibit the burning of agricultural residue. If farmers cannot burn the residue, they have to incur costs to haul the residue away and dispose of it. In this case, the benefits of technologies that do not require the removal of residues would be higher. In fact, our data show that in villages in which the government does not allow farmers to burn the crop residue in the field, the adoption of CT technology occurs at a higher rate (table 5).

Finally, having access to information about the attributes of the technology and the ways that the new technology should be used in the field should also improve the likelihood of adoption. Therefore, we should expect areas with access to extension agents (who are promoting CT technology in their villages/ townships) to adopt the technology at higher rates. According to our data, for the villages in which farmers were using CT technology, there was a relatively good opportunity for farmers to access information about the cost and benefits of CT technology through a CT technology extension project (in 63\% of the villages adopting Full CT technology and $27 \%$ of the villages adopting Partial CT technology) (table 5). In contrast, for those villages that did not adopt any kinds of CT 


\section{Table 6}

Regression analysis of the determinants of the adoption of conservation tillage (CT) at the village level (multinomial logit).

\begin{tabular}{|c|c|c|c|c|c|c|}
\hline & \multicolumn{6}{|c|}{ Adoption of CT technology } \\
\hline & \multicolumn{2}{|c|}{ Specification 1} & \multicolumn{2}{|c|}{ Specification 2} & \multicolumn{2}{|c|}{ Specification 3} \\
\hline & Full CT & Partial CT & Full CT & Partial CT & Full CT & Partial CT \\
\hline $\begin{array}{l}\text { Subsidy for machinery } \\
(1=\text { yes; } 0=\text { no })\end{array}$ & $\begin{array}{l}0.0373 \dagger \\
(0.99)\end{array}$ & $\begin{array}{l}0.2452 \\
(1.31)\end{array}$ & & & & \\
\hline $\begin{array}{l}\text { Ban against burning residue } \\
\quad(1=\text { yes; } 0=\text { no })\end{array}$ & & & $\begin{array}{l}0.2296 \\
(1.79)^{*}\end{array}$ & $\begin{array}{l}0.0007 \\
(1.75)^{*}\end{array}$ & & \\
\hline $\begin{array}{l}\text { Has CT project } \\
(1=\text { yes; } 0=\text { no })\end{array}$ & & & & & $\begin{array}{c}0.0891 \\
(2.49)^{* *} \\
\end{array}$ & $\begin{array}{l}0.2372 \\
(2.38)^{* *} \\
\end{array}$ \\
\hline \multicolumn{7}{|l|}{ Village characteristics } \\
\hline Share of off-farm labor & $\begin{array}{l}0.0027 \\
(2.93)^{* * *}\end{array}$ & $\begin{array}{c}0.0026 \\
(1.80)^{* *}\end{array}$ & $\begin{array}{l}0.0039 \\
(2.37)^{* *}\end{array}$ & $\begin{array}{l}0.0014 \\
(1.66)^{*}\end{array}$ & $\begin{array}{l}0.0021 \\
(2.86)^{* *}\end{array}$ & $\begin{array}{l}0.0034 \\
(2.09)^{* *}\end{array}$ \\
\hline Distance to township $(\mathrm{km})$ & $\begin{array}{l}0.0049 \\
(0.63)\end{array}$ & $\begin{array}{l}-0.0126 \\
(0.71)\end{array}$ & $\begin{array}{l}0.0022 \\
(0.13)\end{array}$ & $\begin{array}{l}-0.0126 \\
(0.83)\end{array}$ & $\begin{array}{l}0.0060 \\
(1.26)\end{array}$ & $\begin{array}{l}-0.0090 \\
(0.4)\end{array}$ \\
\hline County dummy & $\begin{array}{l}\text { Not } \\
\text { reporting } \\
\text { the results }\end{array}$ & $\begin{array}{l}\text { Not } \\
\text { reporting } \\
\text { the results }\end{array}$ & $\begin{array}{l}\text { Not } \\
\text { reporting } \\
\text { the results }\end{array}$ & $\begin{array}{l}\text { Not } \\
\text { reporting } \\
\text { the results }\end{array}$ & $\begin{array}{l}\text { Not } \\
\text { reporting } \\
\text { the results }\end{array}$ & $\begin{array}{l}\text { Not } \\
\text { reporting } \\
\text { the results }\end{array}$ \\
\hline Constant & $\begin{array}{l}-1.7852 \\
(0.57)\end{array}$ & $\begin{array}{l}0.8724 \\
(0.54)\end{array}$ & $\begin{array}{l}-5.7104 \\
(0.54)\end{array}$ & $\begin{array}{l}1.0528 \\
(0.67)\end{array}$ & $\begin{array}{l}-6.3037 \\
(1.40)\end{array}$ & $\begin{array}{l}-0.8109 \\
(0.44)\end{array}$ \\
\hline Observations & 98 & & 98 & & 98 & \\
\hline Pseudo $\mathrm{R}^{2}$ & 0.28 & & 0.33 & & 0.32 & \\
\hline Probability $>\mathrm{Chi}^{2}$ & 0.0018 & & 0.0001 & & 0.0002 & \\
\hline
\end{tabular}

Notes: In specification 1, only the variable "subsidy for machinery" was included in the regression. In specification 2, only the variable "forbid burning residue" was included. In specification 3, only the variable "having CT project" was included. Full CT implies that villages/farmers adopt both reduced till and residue retention together. Partial CT implies that villages/farmers that only adopt one of the components of Full CT technology-either reduced tillage or residue retention. The absolute value of $Z$ statistics is in parentheses. Coefficients here are marginal effect: share of off-farm labor increases by 0.01 , per capita cultivated land increased by 0.1 , and share of irrigated land area increases by 0.01 .

$\dagger$ Indicates that in these villages have a conservation tillage project implemented by other programs or organizations.

* significant at $10 \% * *$ significant at $5 \% * * *$ significant at $1 \%$

technology, only $6 \%$ of them had had any opportunity to participate in a CT technology extension project.

Conservation tillage technology extension projects took on a number of forms. In some cases, an extension meeting was held. During the meetings, agronomists from the project provided lectures on the theory and practice of CT technology. There were also segments of the training sessions that presented some of the key technical issues on how farmers may be able to successfully adopt CT technology in their fields. In other cases (perhaps in the case of the CT project that most important form of extension activity), project agronomists established a series of demonstration pilot sites. These were put in both the experiment station and in the villages. The purpose was to show farmers the potential benefits (as well as spell out the costs) of CT technology adoption. Finally, the project also was engaged in capacity building. Specialists from Beijing and other universities trained local extension personnel on the benefits and costs (and other training issues) of CT technology.

Similar results were found when looking at the household-level measures of technology adoption. For example, if the household has more family members working off the farm, the probability that the household will adopt some type of CT technology is higher $30 \%$ or $31 \%$ for those households adopting the full or partial CT technology versus $17 \%$ for nonadopted households) (table 5). Those households with more land also seem relatively more willing to adopt Full CT technology (table 5). Similar to the village-level data, however, it does not appear that the adoption of Partial CT technology is constrained by the land resource endowment (table 5). In our household descriptive statistics, in the same way as is seen in the village-level descriptive statistics, there is evidence that the scarcity of factor endowments plays an important role in encouraging technology adoption-and this effect is particularly pronounced in the case of Full CT technology. Interestingly, Lin (1992) in a paper on hybrid rice adoption, found similar results in his sample of Hunan farmers.

Our household-level data also suggest that policy and extension can play a role in encouraging adoption. First, from our household-level data, we see that those households with less wealth adopt less of the Partial CT technology (table 5). There could be a wealth constraint since CT technology involves some potential yield loss and the investment into new machinery. Therefore, it is not sur- 
Table 7

Regression analysis of the determinants of the adoption of conservation tillage (CT) technology at household level (multinomial logit).

\begin{tabular}{|c|c|c|c|c|}
\hline & \multicolumn{4}{|c|}{ Adoption of CT technology } \\
\hline & \multicolumn{2}{|c|}{ Specification 1} & \multicolumn{2}{|c|}{ Specification 3} \\
\hline & Full CT & Partial CT & Full CT & Partial CT \\
\hline \multicolumn{5}{|l|}{ Policy intervention } \\
\hline Ban against burning residue & 0.0603 & 0.0289 & & \\
\hline$(1=$ yes; $0=$ no $)$ & $(2.15)^{* *}$ & $(1.44)$ & & \\
\hline \multicolumn{5}{|l|}{ Extension project implementation } \\
\hline Participated in CT project† & & & 0.0579 & 0.2615 \\
\hline$(1=$ yes; $0=$ no $)$ & & & $(1.80)$ * & $(3.11) * * *$ \\
\hline \multicolumn{5}{|l|}{ Household characteristics } \\
\hline Share of off-farm labor & $\begin{array}{l}0.0007 \\
(2.45)^{* *}\end{array}$ & $\begin{array}{c}0.0012 \\
(2.18)^{* *}\end{array}$ & $\begin{array}{c}0.0006 \\
(2.23)^{* *}\end{array}$ & $\begin{array}{l}0.0012 \\
(2.23)^{* *}\end{array}$ \\
\hline Per capita cultivated land area (ha) & $\begin{array}{l}0.0030 \\
(1.67)^{*}\end{array}$ & $\begin{array}{l}0.0003 \\
(0.57)\end{array}$ & $\begin{array}{l}0.0033 \\
(1.92)^{*}\end{array}$ & $\begin{array}{l}0.0017 \\
(0.90)\end{array}$ \\
\hline Share of irrigated plots & $\begin{array}{l}-0.0008 \\
(0.89)\end{array}$ & $\begin{array}{l}0.0015 \\
(1.30)\end{array}$ & $\begin{array}{l}-0.0007 \\
(0.88)\end{array}$ & $\begin{array}{l}0.0011 \\
(0.85)\end{array}$ \\
\hline $\begin{array}{l}\text { Owns draft animals } \\
(1=\text { yes; } 0=\text { no })\end{array}$ & $\begin{array}{l}-0.0163 \\
(1.10)\end{array}$ & $\begin{array}{l}-0.1109 \\
(2.16)^{* *}\end{array}$ & $\begin{array}{l}0.0059 \\
(0.48)\end{array}$ & $\begin{array}{l}-0.0977 \\
(1.77)^{\star}\end{array}$ \\
\hline Value of house (yuan) (log) & $\begin{array}{l}-0.0014 \\
(0.71)\end{array}$ & $\begin{array}{l}0.0396 \\
(2.01)^{* *}\end{array}$ & $\begin{array}{l}-0.0045 \\
(0.49)\end{array}$ & $\begin{array}{l}0.0424 \\
(2.06)^{* *}\end{array}$ \\
\hline Age of household head (years) & $\begin{array}{l}0.0108 \\
(0.11)\end{array}$ & $\begin{array}{l}-0.0449 \\
(2.43)^{* *}\end{array}$ & $\begin{array}{l}0.0048 \\
(0.38)\end{array}$ & $\begin{array}{l}-0.0424 \\
(2.67)^{\star *}\end{array}$ \\
\hline Age of household head, squared & $\begin{array}{l}-0.0001 \\
(0.12)\end{array}$ & $\begin{array}{c}0.0005 \\
(2.43)^{* *}\end{array}$ & $\begin{array}{l}-0.0001 \\
(0.34)\end{array}$ & $\begin{array}{l}0.0005 \\
(2.67)^{* *}\end{array}$ \\
\hline Education of household head (years) & $\begin{array}{l}-0.0036 \\
(1.21)\end{array}$ & $\begin{array}{l}-0.0085 \\
(1.43)\end{array}$ & $\begin{array}{l}-0.0046 \\
(1.51)\end{array}$ & $\begin{array}{l}-0.0004 \\
(1.58)\end{array}$ \\
\hline Share of loam plots & $\begin{array}{l}0.0007 \\
(0.85)\end{array}$ & $\begin{array}{l}-0.0011 \\
(0.64)\end{array}$ & $\begin{array}{l}0.0747 \\
(0.64)\end{array}$ & $\begin{array}{l}-0.0993 \\
(0.56)\end{array}$ \\
\hline Share of clay plots & $\begin{array}{l}-0.0525 \\
(2.31)^{* *}\end{array}$ & $\begin{array}{l}-0.0617 \\
(1.31)\end{array}$ & $\begin{array}{l}-0.0487 \\
(2.11)^{* *}\end{array}$ & $\begin{array}{l}-0.0596 \\
(1.27)\end{array}$ \\
\hline County dummy & $\begin{array}{l}\text { Not } \\
\text { reporting } \\
\text { the results }\end{array}$ & $\begin{array}{l}\text { Not } \\
\text { reporting } \\
\text { the results }\end{array}$ & $\begin{array}{l}\text { Not } \\
\text { reporting } \\
\text { the results }\end{array}$ & $\begin{array}{l}\text { Not } \\
\text { reporting } \\
\text { the results }\end{array}$ \\
\hline Constant & $\begin{array}{l}-2.2567 \\
(0.20)\end{array}$ & $\begin{array}{c}6.1892 \\
(1.84)^{*}\end{array}$ & $\begin{array}{l}2.4283 \\
(0.25)\end{array}$ & $\begin{array}{l}5.5909 \\
(1.67)\end{array}$ \\
\hline Observations & 288 & & 288 & \\
\hline Pseudo $\mathrm{R}^{2}$ & 0.46 & & 0.47 & \\
\hline Probability $>\mathrm{Chi}^{2}$ & 0.0000 & & 0.0000 & \\
\hline
\end{tabular}

Notes: In specification 1, only the variable "subsidy for machinery" was included in the regression. In specification 3, only the variable "having CT project" was included. Full CT implies that villages/farmers adopt both reduced till and residue retention together. Partial CT implies that villages/ farmers that only adopt one of the components of Full CT technology-either reduced tillage or residue retention. The absolute value of $Z$ statistics is in parentheses. Coefficients here are marginal effect: share of off-farm labor increases by 0.01 , per capita cultivated land increased by 0.1 , and share of irrigated land area increased by 0.01 .

$\dagger$ Indicates that in these villages have conservation tillage project implemented by other programs or organizations.

* significant at $10 \% * *$ significant at $5 \% * * *$ significant at $1 \%$

prising that the results of our village-level descriptive statistic found that government subsidy policies helped encouage CT technology adoption. Compared with Partial CT technology, however, the adoption of Full CT technology appears to be less constrained by wealth (table 5).

In addition, even though rates of adoption are relatively low, there are still differences between farmers in regions where they are affected by different government regulations and when they have differential access to government extension programs. For example, in the case of those households that adopted CT technology, $53 \%$ of Full CT technology adopters and $28 \%$ of Partial $\mathrm{CT}$ adopters stated that they lived in villages in which the government does not allow them to burn the residue of their crops; only $19 \%$ of nonadopters lived in such localities (table 5). The importance of extension efforts is also seen by noting that $76 \%$ of households that had adopted some type of CT technology (34\% in the case of Partial technology) had at some point in the past participated in an extension training program on $\mathrm{CT}$ technology; it was only $6 \%$ in the case of nonadopting households.

Multivariate Analysis Results. During the estimation using a commercial package 


\section{Table 8}

Regression analysis of the determinants of adoption of conservation agriculture technology at village level (multinomial logit).

\begin{tabular}{lcc}
\hline & \multicolumn{2}{l}{ Adoption of CT technology } \\
\cline { 2 - 3 } & Full CT & Partial CT \\
\hline Policy intervention & & 0.0866 \\
\hline Interaction term of ban against & $0.1210 \dagger$ & $(1.21)$ \\
burning residue policy and has & $(2.27)^{* *}$ & \\
CT project & & 0.0032 \\
\hline Village characteristics & & $(2.04)^{* *}$ \\
\hline Share of off-farm labor & 0.0026 & -0.0503 \\
& $(2.85)^{* * *}$ & $(1.52)$ \\
Per capita cultivated land area (ha) & -0.0070 & 0.0022 \\
& $(0.64)$ & $(1.27)$ \\
Share of irrigated land area & 0.0010 & -0.0099 \\
Distance to township (km) & $(1.56)$ & $(0.50)$ \\
& 0.0055 & Not reporting \\
County dummy & $(0.92)$ & the results \\
& Not reporting & 0.7286 \\
Constant & the results & $(0.46)$ \\
Observations & -2.9724 & \\
Pseudo $\mathrm{R}^{2}$ & $(0.69)$ & \\
Probability $>$ Chi ${ }^{2}$ & 98 & 0.2978 \\
\hline
\end{tabular}

Notes: Full CT implies that villages/farmers adopt both reduced till and residue retention together. Partial CT implies that villages/farmers that only adopt one of the components of Full CT technology-either reduced tillage or residue retention.

† The absolute value of $Z$ statistics is in parentheses. Coefficients here are marginal effect: share of off-farm labor increases by 0.01 , per capita cultivated land increased by 0.1 , and share of irrigated land area increased by 0.01 .

* significant at $10 \% * *$ significant at $5 \% * * *$ significant at $1 \%$

Stata, we tried several different specifications for both the village-level (equation 1) and household-level models (equation 2). It is possible that there is multicollinearity between several of our key policy variables. For example, it could be that in places in which the government banned the burning of crop residue, they also gave subsidies to farmers for purchasing the machinery. When farm machinery is subsidized, the price that the famers paid for the machinery would be lower than the price if it were purchased on the market. The same is true in areas that have promoted CT technology (they might also be the areas that provide machinery subsidies or ban residue burning). In other words, it is possible that policies come in packages, which would make identifying individual effects difficult. In our analysis, we deal with this by including the policy variables separately.

Based on the above discussion, we use three alternative model specifications for the village-level analysis (table 6). In specification 1 , we only included the variable "subsidy for machinery" in the regression. In specifica- tion 2 , we only included the variable "forbid burning residue." In specification 3, we only included the variable "having CT project." For the household level analysis, we use two alternative specifications (table 7). The two specifications for the household level analysis are similar to specification 1 and 3 in the village-level analysis. For both the village-level and household-level analyses, we also included an interaction term between the "residue burning ban" policy and extension activity. The results do not change much when comparing them with the model specifications in tables 4 and 5 (tables 8 and 9).

In using the multinomial logit approach to estimate the different specifications of equation 1, it appears that the models perform relatively well. The goodness of fit measures, the Pseudo $\mathrm{R}^{2}$ statistics, range from 0.28 to 0.33 for the village-level models (table 6). These levels of measures mean that the fit is relatively good for this type of an analysis. The household-level model also performed well. The Pseudo $\mathrm{R}^{2}$ statistics (from 0.46 to 0.47) also suggest that the model fits well (table 7).
Many of the coefficients of the control variables in the equations are statistically significant. For example, when examining the household-level model, those farmers that cultivate land which is dominated by clay soils rarely adopt Full CT technology (table 7). When the share of plots that are made up of clay soil increases by $1 \%$, the likelihood of adopting the full CT is reduced about $5 \%$. Hence, it appears that farmers are rationale in their decision to adopt CT technologies. When soils are made of clay, there is less of an imperative to adopt soil-conserving technologies. In fact, extension agents do not encourage those farmers that are cultivating crops on clay soils to use Full CT technology since the penetration of water and germination is poorer in such soils if Full CT technology is used. Having draft animals will constrain the adoption of Partial CT technology. The adoption of Partial CT technology also is correlated with the age of the household head.

More importantly, we find in the multivariate analysis that the adoption of CT technology is affected by the factor endowments that characterize villages and farm households. Specifically, the coefficient of the variable measuring the opportunity cost of the farm household (the share of labor force of the village/family that is in the off-farm sector) is positive and statistically significant in both the village- and household-level models for both the adoption of Full and Partial CT technology (tables 6 and 7). If the share of the labor force that works off the farm increases by the $1 \%$, according to the results, the propensity of farmers to adopt Full CT technology will increase by $0.1 \%$ to $0.4 \%$. This finding also is consistent with the fact that CT technology is labor saving. When families have more members in the off-farm labor market, they are looking for ways to save labor and thus adopt CT technology more often. However, it is interesting that the magnitude of the coefficient is relatively small. In the household-level model, the coefficient on the land variable is positive and significant in the Full CT adoption model. In other words, the results suggest that farmers with less labor and/or more land adopt Full and Partial CT technology more frequently (table 7). Hence, factor endowments appear to be one of important determinants of CT technology adoption.

We also see evidence in our multivariate analysis that switching technologies may be expensive. From our household-based analysis, the coefficient on the wealth variable (which is positive and significant) suggests that 
rich farmers are more likely to adopt Partial CT technology than poor ones (table 7). In addition, the coefficients on the variables that measure the presence of a local policy to subsidize machinery (which could help alleviate the wealth constraint) is positive in the village level model (table 6). Together, these results suggest that-after keeping constant the other variables-a policy that seeks to assist farmers in financing their initial adoption indeed appears to promote the adoption of CT technology.

Our results - also as seen in the descriptive statistics-demonstrate the importance of other policy efforts, including government initiatives to run extension projects. The success of these policies appears to be mainly due to the strong administrative management system of central and local governments. For example, in order to implement the policy that bans the burning of residue in the field (and also in order to teach farmers that they are not allowed to burn the residue), the local government (at the direction of upper-level governments) organized several different types of activities. First, they held extension meetings. In addition, they assigned local officials to monitor the burning activities in the field. According to the joint regulation between Ministry of Environmental Protection and Ministry of Agriculture, if local officials discover that farmers are burning residue, farmers will be fined (Ministry of Environmental Protection and Ministry of Agriculture 2008). In the CT demonstration project sites, the central and local government agencies have established monitoring stations as well as a network of extension agents.

When policies that ban the burning of residues are actively promoted (and perhaps effectively enforced), the village- and household-level regressions show that the adoption rates of CT technology (either Full or Partial technology) rise (table 6). For example, when implementing the policy of banning residue burning, the likelihood for households to adopt the Full CT technology will increase by $6 \%$. Moreover, when villages host extension projects featuring CT technology (also either Full or Partial CT technology), the positive and significant coefficients on the variables measuring these extension efforts also are positive and statistically significant (table 6). So, likewise, when there is a local program to extend the adoption of the Full CT technology, the propensity of farmers to adopt the technology increases by $9 \%$. Taken

Table 9

Regression analysis of the determinants of adoption of conservation agriculture technology at household level (multinomial logit).

\begin{tabular}{|c|c|c|}
\hline & \multicolumn{2}{|c|}{ If adopt CT technology } \\
\hline & Full CT & Partial CT \\
\hline \multicolumn{3}{|l|}{ Policy intervention } \\
\hline $\begin{array}{l}\text { Interaction term of ban against burning } \\
\text { residue and participating in CT project }\end{array}$ & $\begin{array}{l}0.1170 \\
(3.34)^{* * *}\end{array}$ & $\begin{array}{l}0.1841 \\
(2.52)^{* *}\end{array}$ \\
\hline \multicolumn{3}{|l|}{ Household characteristics } \\
\hline Share of off-farm labor & $\begin{array}{l}0.0007 \\
(2.53)^{* *}\end{array}$ & $\begin{array}{l}0.0012 \\
(2.21)^{* *}\end{array}$ \\
\hline Per capita cultivated land area (ha) & $\begin{array}{l}0.0029 \\
(1.70)^{*}\end{array}$ & $\begin{array}{l}0.0017 \\
(0.81)\end{array}$ \\
\hline Share of irrigated plots & $\begin{array}{l}-0.0010 \\
(1.18)\end{array}$ & $\begin{array}{l}0.0016 \\
(1.28)\end{array}$ \\
\hline Has draft animals ( $1=$ yes; $0=$ no $)$ & $\begin{array}{l}-0.0159 \\
(1.24)\end{array}$ & $\begin{array}{l}-0.1202 \\
(2.33)^{* *}\end{array}$ \\
\hline Value of house (yuan) (log) & $\begin{array}{l}-0.0039 \\
(1.23)\end{array}$ & $\begin{array}{l}0.0376 \\
(2.13)^{* *}\end{array}$ \\
\hline Age of household head (years) & $\begin{array}{l}0.0205 \\
(0.64)\end{array}$ & $\begin{array}{l}-0.0513 \\
(2.40)^{* *}\end{array}$ \\
\hline Age of household head, (squared) & $\begin{array}{l}-0.0002 \\
(0.61)\end{array}$ & $\begin{array}{l}0.0005 \\
(2.45)^{* *}\end{array}$ \\
\hline Education of household head (years) & $\begin{array}{l}-0.0023 \\
(0.97)\end{array}$ & $\begin{array}{l}-0.0086 \\
(1.34)\end{array}$ \\
\hline Share of loam plots & $\begin{array}{l}0.0007 \\
(0.68)\end{array}$ & $\begin{array}{l}-0.0012 \\
(0.79)\end{array}$ \\
\hline Share of clay plots & $\begin{array}{l}-0.0554 \\
(2.71)^{* * *}\end{array}$ & $\begin{array}{l}-0.0806 \\
(1.58)\end{array}$ \\
\hline County dummy & $\begin{array}{l}\text { Not reporting } \\
\text { the results }\end{array}$ & $\begin{array}{l}\text { Not reporting } \\
\text { the results }\end{array}$ \\
\hline Constant & $\begin{array}{c}-11.0943 \\
(0.86)\end{array}$ & $\begin{array}{l}5.4507 \\
(1.59)\end{array}$ \\
\hline Observations & 288 & \\
\hline Pseudo $\mathrm{R}^{2}$ & 0.4791 & \\
\hline Prob $>\mathrm{Chi}^{2}$ & 0.0000 & \\
\hline
\end{tabular}

Notes: Full CT implies that villages/farmers adopt both reduced till and residue retention together. Partial CT implies that villages/farmers that only adopt one of the components of Full CT technology-either reduced tillage or residue retention. The absolute value of $Z$ statistics is in parentheses. Coefficients here are marginal effect: share of off-farm labor increases by 0.01 , per capita cultivated land increased by 0.1 , and share of irrigated land area increased by 0.01 .

* significant at $10 \% * *$ significant at $5 \% * * *$ significant at $1 \%$

together, it can be seen that two of the most important policies can increase the adoption by $15 \%$, not a small amount. Therefore, the government clearly appears to have a role in the future extension of CT technology.

\section{Summary and Conclusions}

Despite the widespread adoption of CT technology in other countries (such as in the United States, Canada, and Brazil), adoption of CT technology in China is relatively low. Our paper shows that this is particularly true for adoption of Full CT technology. Few farmers in China have chosen to adopt a package of technology that includes both no tillage or reduced tillage and residue retention together. In other words, in the mid-2000s, the adoption rates of the Full CT technology package was only around $1 \%$. Although our data show that the adoption of Partial CT technology (either no tillage or reduced tillage or residue retention) in China is higher and is rising steadily, overall, it has not spread enough to become a true technological force (and it is not clear if the adoption of Partial CT technology is truly the first step to the adoption of Full CT technology). It is in this sense that we can say in China that the state of CT technology adoption is lagging.

However, that does not mean the Blue Revolution will not occur in China in the future. In fact, we believe that the answer 
to the question regarding when the Blue Revolution will begin to gain strength begins with the question: Why is it that-so far-farmers in China have not enthusiastically adopted CT technology as they have in certain other regions of the world? According to our analysis, one of the most apparent reasons is that-at least in the past-the nature of China's agricultural production practices did not really provide a close fit for the benefits of CT technology. Traditionally, labor costs per unit of input for farmers in China have been low, and the share of all production costs accounted for by machinery/fuel costs are also low. Therefore, while farmers in China certainly would be happy to save labor and machinery costs, they have little incentive to embrace CT technology. This is particularly true since at least in the first years of adoption, it is not clear if CT technology can result in higher yields, a trait that is most prized by farmers where land is scarce, such as China.

What is the future of China's Blue Revolution? If it is true-in the way that our descriptive and multivariate results showthat the policy environment is right, more farmers will likely adopt CT technology. For example, if subsidies were expanded, if regulations that banned residue burning were set, or if there was a greater effort in pro-CT technology extension initiatives, the adoption of CT technology by China's farmers would be expected to rise. However, most likely it is going to be shifts in the value of factor endowments that will ultimately give the biggest boost to the revolution. When wage rates rise-as they have been doing in recent years - and as the demand for machinery and fuel increases (as capital replaces labor in China's fields), we believe the demand for labor-saving and machinery/fuel-saving technologies will rise.

\section{Acknowledgements}

The authors would like to thank Erika Meng, who was a senior researcher,John Dixon, a senior researcher, Ken Sayre, a senior researcher, and Roberto La Rovere, a senior researcher at the International Wheat and Maize Improvement Center, Mexico City, Mexico, and Mark Giordano, a senior researcher at the International Water Management Institute, Colombo, Sri Lanka, for their insights and helpful suggestions. We also would like to thank all enumerators for their efforts in data collection and collaborators for their kind help in arranging the field survey. We acknowledge financial support from the Challenge Program of the Consultant Group of International Agricultural Research (CPWFYRB200507), National Natural Science Foundation of China (70733004, 70925001) and the Knowledge Innovation Program of the Chinese Academy of Sciences (KSCX-YW-09-04).

\section{References}

ACIAR (Australian Centre for International Agricultural Research). 2005. Production, New Skills and a Sustainable Hope in Gansu, Partners in Research for Development, April 2005. Canberra: Australian Centre for International Agricultural Research.

Assunção, J.J. 2005. Non-agricultural land use and land reform: Theory and evidence from Brazil. Textos Para Discuss Ãfo 496, Department of Economics PUC-Rio (Brazil).

Baudron, F., H.M. Mwanza, B. Troimphe, and M. Bwalya. 2007. Conservation agriculture in Zambia: A case study of southern province. African Conservation Tillage Network. Nairobi, Kenya: Food and Agricultural Organization of the United Nations.

Barker, T., I. Bashmakov, L. Bernstein, J.E. Bogner, P.R. Bosch, R. Dave, O. Davidson, B.S. Fisher, S. Gupta, K. Halsnæs, B.J. Heij, S.K. Ribeiro, S. Kobayashi, M.D. Levine, D.L. Martino, O. Masera, B. Metz, L. Meyer, G.-J. Nabuurs, A. Najam, N. Nakicenovic, H.-H. Rogner, J. Roy, J. Sathaye, R. Schock, P. Shukla, R.E.H. Sims, P. Smith, D.A. Tirpak, D. Urge-Vorsatz, and D. Zhou. 2007 Technical summary. In Climate Change 2007 Mitigation. Contribution of Working Group III to the Fourth Assessment Report of the Intergovernmental Panel on Climate Change, ed. B. Metz, O.R. Davidson, P.R Bosch, R. Dave, and L.A. Meyer. Cambridge, UK and New York, NY: Cambridge University Press.

Bekele, W. 2003. Theory and Empirical Application to Subsistence Farming in the Eastern Ethiopian Highlands. PhD dissertation, Department of Economics, Swedish University of Agricultural Sciences.

Bolliger, A., J. Magid, T.J.C. Amado, F.S. Neto, M.D.D. Ribeiro, A. Calegari, R. Ralisch, and A. de Neergaard. 2006. Taking stock of the Brazilian "zero-till revolution": A review of landmark research and farmers' practice. Advances in Agronomy 91:47-110.

Brauw, A.D., Q. Li, C. Liu, S. Rozelle, and L. Zhang. 2008. Feminization of agriculture in China? Myth surrounding women's participation in farming. The China Quarterly 194( June):327-348

Byerlee, D., and E.H. de Polanco, 1986. Farmers' stepwise adoption of technological packages: Evidence from Mexican Altiplano. American Journal of Agricultural Economics 68:519-527.

Cai, Q. 2002. The Relationships between Soil Erosion and Human Activities on the Loess Plateau, 12th ISCO Conference, Beijing.
Cao, S., C. Xu, C. Li, and X. Wang. 2008. Attitudes of farmers in China's Northern Shaanxi Province towards the landuse changes required under the Grain for Green Project, and implications for the project's success. Land Use Policy. 26(4):1182-1194.

CIMMYT (International Maize and Wheat Improvement Center). 1993.The Adoption of Agricultural Technology: A Guide for Survey Design. Mexico: International Maize and Wheat Improvement Center.

Clay, D.C., V. Kelly, E. Mpyisi, and T. Reardon. 2002. Input use and soil conservation investments among farm households in Rwanda: Patterns and determinants. In Natural Resources Management in African Agriculture, ed. C.B. Barrett, F. Place, and A.A. Aboud. New York, NY: CTBI International.

Crosson, P. 1981. Conservation Tillage and Conventional Tillage: A Comparative Assessment. Ankeny, IA: Soil Conservation Society of America.

CTIC (Conservation Technology Information Center). 2002. Tillage Type Definitions. Lafayette, IN: CTIC, Core 4 Program.

Den Biggelaar, C., R. Lal, H. Eswaran, V. Breneman, and P. Reich. 2003. Crop yield losses to soil erosion at regional and global scales: Evidence from plot-level and GIS data. In Land Quality, Agricultural Productivity, and Food Security: Biophysical Processes and Economic Choices at Local, Regional, and Global Levels, ed. Keith Wiebe, 262-279. Cheltenham, UK, and Northampton, MA, USA: Edward Elgar.

Department for Environment, Food and Rural Affairs. 2005. Controlling Soil Erosion: A Manual for the Assessment and Management of Agricultural Land at Risk of Water Erosion in Lowland England. Department for Environment, Food and Rural Affairs Publications. Product Code PB4093.

Des Raj, P.C. 1998. Sample Survey Theory, Narosa Publishing House, India.

Ding, Y., S. Wang, and R. Wang. 1994. Effects of no-tillage with whole stalk half mulch on corn growth and development and yield in dry land. Journal of Maize Sciences 2(1):28-31.

Dou, L. 2007.Analysis of the reasons why conservation tillage increases significantly the yield of wheat. Agriculture Machinery Technology Extension 7:25-26.

ECCP (European Climate Change Programme). 2003. Working Group Sinks Related to Agricultural Soils. Final Report: 75 .

Ervin, C.A., and D.E. Ervin. 1982. Factors affecting the use of soil conservation practices: Hypotheses, evidence and policy implications. Land Economics 58:277-292.

FAO (Food and Agriculture Organization). 2001a. Intensifying crop production with Conservation Agriculture. Rome: Food and Agriculture Organization of the United Nations. 
FAO. 2001b. The Economics of Conservation Agriculture. Rome: Food and Agriculture Organization of the United Nations.

FAO. 2001c. Economics of Soil Productivity in Sub-Saharan Africa. Rome: Food and Agriculture Organization of the United Nations.

FAO. 2006. Conservation Agriculture. Rome: Food and Agriculture Organization of the United Nations.

Faulkner, E.H. 1943. Fraulkner, Plowman's Folly. Norman, OK: University of Oklahoma Press.

Field, B.C. 2001. Natural Resource Economics - An Introduction. New York, NY: McGraw Hill.

Gao, H. 2006. Trends and problems of conservation tillage in China. Shandong Mechanization of Agriculture 10:9.

Geraghty, J. 2007. The blue revolution. Farm Management, January 6, 2007: 22-23.

Gill, K.S., and B.S. Aulakh. 1990. Wheat yield and soil bulkdensity response to some tillage systems on an oxisol. Soil \& Tillage Research 18:37-45.

Giller, K.E., E. Witter, M. Corbeels, and P. Tittonell. 2009. Conservation agriculture and smallholder farming in Africa: The heretics' view. Field Crops Research 114(1):23-34.

Greene, W.H. 1997. Econometric Analysis (Third Edition), 914-916. New York: New York University, Prentice-Hall International, Inc.

Gu, Z. 2008. The central government has invested 0.17 billion yuan for the conservation tillage which reached more than 30 million mu. 3 May, People Daily.

He, Q., P. Tong, S. Bian, and L. Zhang. 2004. The influence of long-term minimum tillage on (cron) yield and soil ecological surroundings. Journal of Maize Sciences 12:99-102.

Huang, D. 1988. Soil fertility and fertilization under the condition of no-till or reduced till. Chinese Journal of Soil Science 2:93-99.

Huang, J., and S. Rozelle. 1996. Technological change: Rediscovering the engine of productivity growth in China's rural economy. Journal of Development Economics 49:337-369.

Huang, J., S. Rozelle, C. Pray, and Q. Wang. 2002. Plant biotechnology in China. Science 295:674-677.

Huszar, P.C., D. Sanders, S. Sombatpanit and T. Enters, ed. 1999. Incentives in Soil Conservation: From Theory to Practice. Enfield, NH: Science Publishing Inc.

Ji, Z., S. Zhang, and Z. Xue. 1998. A study on soil nutrient with no tillage in arid cornfield soil organic matter, enzyme and nitrogen. Acta Agriculturae Boreali-Sinica $13(2): 42-47$.

Jiao, J., Y. Jia, K. Jing, and W. Wang. 2008. Natural soil erosion, Soil loss tolerance and criterion of soil and water conservation. Science of Soil and Water Conservation 6(4):77-84.
Kang, H., B. Zhu, L. Hong, and C. Dong. 2001. Effects of no-tillage with straw mulching on soil fertility and wheat yield in dryland. Shaanxi Journal of Agricultural Sciences 9:1-3.

Kaumbutho, P., and J. Kienzle. 2007. Conservation Agriculture as Practiced in Kenya: Two Case Studies. African Conservation Tillage Network, Centre de Coopération Internationale de Recherche Agronomique pour le (Développement). Nairobi, Kenya: Food and Agriculture Organization of the United Nations.

Knowler, D., and B. Bradshaw. 2007. Farmers' adoption of conservation agriculture: A review and synthesis of recent research, Food Policy 32:25-48.

Lal, R., J.M. Kimble, R.F. Follet, and C.V. Cole. 1999. The Potential of U.S. Cropland to Sequester Carbon and Mitigate the Greenhouse Effect. Boca Raton: Lewis Publishers.

Li, L. 1999. New technology of minimum tillage with stubble and straw mulching during the whole growth period of wheat. Shaanxi Journal of Agricultural Sciences 4:40-41.

Li, X., Z. Ma, X. Yao, K. Jing, and H. Zhu. 2008. Current status and comprehensive control strategies of soil erosion for rocky mountain areas in the northern China. Science of Soil and Water Conservation 6(1):9-15.

Liu, J. 2008. Technical Research Report on the Experiments of Conservation Agriculture in the Dryland Areas in the Yellow River Basin: Case in Inner Mongolia Province. Report Submitted to the Challenge Program of Consultant Group of International Agricultural Research. Beijing.

Liu, J., H. Gao, and H. Li. 2004. Conservation tillage for corn-wheat two crops a year region. Transactions of the Chinese Society of Agricultural Engineering 3:70-73.

Liu, J., Z. Ji, Z.Yang, and Q. Zhao. 1994. No- and reducedtillage with residue mulching and corn (wheat) production in semi-arid regions. Journal of Shanxi Agricultural Sciences 22(3):1-6.

Liu, J., Y. Zhou, Z. Li, and C. Chen. 1989. Effects of deep loosening and minimum tillage on physiological process of panic. Journal of Desert Research 9(2):39-47.

Lin, J.Y. 1992. Hybrid rice innovation in China: A study of market-demand induced technological innovation in a centrally planned economy. Review of Economics and Statistics 74:14-20.

Lithourgidis, A.S., C.A. Damalas, and I.G. Eleftherohorinos. 2009. Conservation tillage: A promising perspective for sustainable agriculture in Greece. Journal of Sustainable Agriculture 33:85-95.

Ma, Z., X. Bao, S. Liu, and Q. Shu. 2006. Effects of conservation tillage on yield and benefit in the wheat and maize row intercropping system. In Proceedings of the China-Canada Conservation Tillage Forum, 97-103.

Malla,Y.B. 1999. Tree management and household strategies in a changing rural economy: Beyond the use of direct incentives. In Incentives in Soil Conservation:
From Theory to Practice, ed. D.W. Sanders, P.C. Huszar, S. Sombatpanit, and T. Enters, 115. Enfield, NH: Science Publishers Inc.

Mbagwu, J. 1990. Mulch and tillage effects on water transmission characteristics of an ultisol and maize grain yield in SE Nigeria. Pedologie 40:155-168.

Ministry of Agriculture. 2005. Proceedings of National Conservation Agricultural Conference, HuheHaoTe City, Inner Mongolia, China, July.

Ministry of Agriculture. 2008a. Suggestions on the Development of Conservation Agriculture. Beijing: Ministry of Agriculture.

Ministry of Agriculture. 2008b. Technical Points of Conservation Agriculture Implementation. Beijing: Ministry of Agriculture.

Ministry of Environmental Protection. 2008. China's Envirnonment Bulletin in 2008. Beijing: Ministry of Environmental Protection.

Ministry of Environmental Protection and Ministry of Agriculture. 2008. Regulation on Managing Residue Burning (No. 243). Beijing: Ministry of Environmental Protection and Ministry of Agriculture.

Ministry of Water Resources. 2007.Water Resources Bulletin. Beijing: Ministry of Water Resources.

Mitchell, J.P., R.J. Southard, N.M. Madden, K.M. Klonsky, J.B. Baker, R.L. DeMoura, W.R. Horwath, D.S. Munk, J.F. Wroble, K.J. Hembree, and W.W. Wallender. 2006. Transition to conservation tillage evaluated in San Joaquin Valley cotton and tomato (rotations). California Agriculture 62(2):74-79.

Mueller, D.H., R.M. Klemme, and T.C. Daniel. 1985. Shortand long-term cost comparisons of conventional and conservation tillage systems in corn production. Journal of Soil and Water Conservation 40(5):466-470.

National Statistic Bureau of China. 2007. China Statistical Yearbook, China Statistical Publishing House, Beijing, China.

NDRC (National Development Reform Commission in China). 2006. Cost of Agricultural Production Data. Beijing: NDRC.

Olson, K.R., S.A. Ebelhar, and J.M. Lang. 2004. Impacts of conservation tillage systems on maize and soybean yields of eroded (Illinois) soil. Journal of Agronomy 3(1):31-35.

Park, A., F. Cai, and D. Wang. 2008. Can China meet her employment challenges. Working paper. Oxford, England: University of Oxford.

Pierret, A., O. Ribolzi, S. Huon, V. Chaplot, C. Rumpel, J.P. Thiebaux, A. de Rouw, O. Sengtaheuanghoung, and C. Valentin. 2008. Land Use, Soil Erosion and Water Quality: Implications for the Transport and Storage of Nutrients and Contaminants, 21-22 October 2008, Mekong River Secretariat in Vientiane.

Reardon,T., and S.A.Vosti. 1995. Links between rural poverty and the environment in developing countries: Asset categories and investment poverty. World Development 23(9):1495-1506. 
Reardon, T., and S.A. Vosti. 1997. Policy analysis of conservation investments: Extension of traditional technology adoption research. In Sustainability, Growth, and Poverty Alleviation, ed. T. Reardon, and S.A. Vosti. Baltimore, MD:The Johns Hopkins University Press.

Ronald, E.P, and H.P. Shirley. 1984. No-Tillage Agriculture Principles and Practices. Nostrand Reinhold Company.

Sanders, D.W., and D. Cahill. 1999. Where incentives fit in conservation programs. In Incentives in Soil Conservation: From Theory to Practice, ed. D.W. Sanders, P.C. Huszar, S. Sombatpanit, and T. Enters. Enfield, NH: Science Publishers Inc.

Shiferaw, B., and S.T. Holden. 2000. Policy instruments for sustainable land management: The case of highland smallholders in Ethiopia. Agricultural Economics 22:217-232.

Shi, S., H. Hu, and J. Ding. 1990. Mulch seeding with no tillage. Transactions of The Chinese Society of Agricultural Engineering 6(3):31-36.

Shi, J., J. Liu, and F. Wu. 2006. Progress and assessment of research on conservation agriculture. Agricultural Research in the Dry Areas 24(1):205-212.

Sorrenson, W.J. 1997. Financial and Economic Implications of No-tillage and Crop Rotations Compared to Conventional Cropping Systems. TCI Occasional Paper Series No. 9, Rome, FAO.

Sorrenson, W.J., C. Duarte, J. Lòpez Portillo. 1998 Economics of No-till Compared to Conventional Cultivation Systems on Small Farms in Paraguay: Policy and Investment Implications. Soil Conservation Project MAG-GTZ.

Sthiannopkao, S., S. Takizawa, and W. Wirojanajud. 2006. Effects of soil erosion on water quality and water uses in the upper phong watershed. Water Science and Technology 53(2):45-52.

Stonehouse, P.D. 1997. Socio-economics of alternative tillage systems. Soil and Tillage Research 43(1-2):109-130.

Suo, L. 2004. River Management and Ecosystem Conservation in China, Proceedings of the Ninth International Symposium on River Sedimentation October 18 - 21, 2004, Yichang, China. http://www. irtces.org/old/irtces/report/9isrs/LishengSuo.pdf.

Uri, N.D. 2000. An evaluation of the economic benefits and costs of conservation tillage. Environmental Geology 39(3/4): 238-248.

USDA ERS (Economic Research Service). 2008. Data Sets. Commodity Costs and Returns. http://www.ers.usda. gov/Data/CostsAndReturns/.

Wang, F. 2008.Technical Research Report on the Experiment of Conservation Agriculture in the Dryland Areas in the Yellow River Basin: Case in Shandong Province. Report Submitted to the Challenge Program of Consultant Group of International Agricultural Research. Beijing.

Wharton, R., and R. Howes. 2008. Land Rental Considerations. \$ Management. December 2007 - January 2008. http://www.agriculture.gov. sk.ca/AV_Dec07_11.
Xie, R., S. Li, X. Li, Y. Jin, K. Wang, Z. Chu, and S. Gao. 2007. The analysis of conservation tillage in Chinaconservation tillage and crop production: Reviewing the evidence. Acientia Agricultural Ainica 40(9):1914-1924.

Yan, C. 2008.Technical Research Report on the Experiments of Conservation Agriculture in the Dryland Areas in the Yellow River Basin: Case in Shanxi Province. Report Submitted to the Challenge Program of Consultant Group of International Agricultural Research. Beijing.

Yang, S., and T. Song. 2007. Greatly develop the conservation tillage, promote the sustainable development of agriculture: Conservation tillage and practices in China. Agricultural Environment and Development 2007 (4):20-24.

Yang, A., H. Wang, K. Wang, and G. Sun. 2002. Soil Erosion Characteristics and Control Measures in China, the 12th ISCO Conference in Beijing.

Yuan,H.2008.Technical Research Report on the Experiments of Conservation Agriculture in the Dryland Areas in the Yellow River Basin: Case in Ningxia Province. Report Submitted to the Challenge Program of Consultant Group of International Agricultural Research. Beijing.

Zentner, R.P., G.P. Lafond, D.A. Derksen, and C.A. Campbell. 2002. Tillage method and crop diversification: Effect on economic returns and riskiness of cropping systems in a thin black chernozem of the Canadian Prairies. Soil \& Tillage Research 67:9-21.

Zhai, J., and W. Deng. 2000. Flooding, Flood Plain Development and Management in China. Ecosystem Service and Sustainable Watershed Management in Northern China, International Conference, Beijing, P.R China, August 23-25, 2000. 184-192.

Zhao, E., L. Li, F. Xu, and L. Liang. 1998. The technical system of straw mulching in whole wheat growth periods in dryland farming. Acta Agriculturae Boreali-occidentalis Sinica 7(4):86-90.

Zhao, H., and S. Shi. 2006. Benefit analysis on the technology of mechanized conservation tillage. Journal of Agricultural Mechanization Research 8:74-76.

Zhang, L., B. Fang, X. Bian, H. Gao, Z. Liao, and Y. Wang. 1995. Technological effect of subsoiling, notill, and (ini-till) in the cold semiarid region with high altitude. Agricultural Research in the Arid Areas 13(4):75-79.

Zhang, H., W. Gao, and B. Chen, 2005. Research Status, Development Trend and Strategies for Conservation Agriculture, Transactions of China's Agricultural University 10(1):16-20.

Zheng, F, and Y. Yao. 2008. Technical Research Report on the Experiments of Conservation Agriculture in the Dryland Areas in the Yellow River Basin: Case in Henan Province. Report Submitted to the Challenge Program of Consultant Group of International Agricultural Research Beijing.

Zhu, S., Q. Wei, G. Lin, and Z. Zhang. 2007. Talking about conservation farming system and tillage technology. Modernization Agriculture 10:35-38. 